\title{
Assessing temporal and spatial variability of phytoplankton composition in a large reservoir in the Brazilian northeastern region under intense drought conditions
}

\author{
Hortência DE SOUSA BARROSO, ${ }^{1}$ Janaína A. DOS SANTOS,${ }^{2}$ Rozane V. MARINS, ${ }^{1}$ Luiz Drude DE LACERDA ${ }^{*}$ \\ ${ }^{1}$ Instituto de Ciências do Mar, Universidade Federal do Ceará, Av. Abolição 3207, Meireles 60165-081, Fortaleza, CE; ${ }^{2}$ Universidade \\ Estadual do Ceará, Av. Dr. Silas Munguba 1700, Fortaleza 60741-000, CE, Brazil \\ *Corresponding author: 1drude@pq.cnpq.br
}

\begin{abstract}
The present study was carried out in Castanhão Reservoir, a large aquatic system in the Brazilian semi-arid region that serves multiples uses as water drinking supply and intensive fish-cage aquaculture site. In order to understand the effects of environmental conditions on the spatial and temporal variability of the phytoplankton functional groups (FG) and the main 'characterizing taxa', sub-superficial water samples were collected from March 2012 to August 2013, a period distinguished by the continuous drop in reservoir volume due to rainfall shortage. Eighteen functional groups and 102 total phytoplankton taxa were found in the Castanhão reservoir during the study. No significant differences were observed relative to spatial variation of total phytoplankton composition throughout the reservoir (PERMANOVA, $\mathrm{P}>0.05$ ). On the other hand, according to cluster analysis results, three temporal phases have been identified (Similarity Profile, $\mathrm{P}<0.05$ ), based on 102 phytoplankton taxa. The 'characterizing taxa' was found using the Similarity Percentage procedure (cut-off $90 \%$ ), being thus defined as those taxa that contributed the most to the similarity within each temporal phase. Nineteen 'characterizing taxa' described the Castanhão reservoir, with predominance of those typical of mixing and turbidity conditions. Cyanobacteria dominated through the three temporal phases. According to the redundancy analysis, nutrient availability and water transparency were found to influence the phytoplankton temporal dynamics. The phase I (rainy season) was most represented by Planktolyngbya minor/Pl. limnetica $(\mathrm{FG}=\mathrm{S} 1)$, which reached best performance under strongly decreased phosphate-P concentrations and low water transparency. In phase II (dry season), Pseudanabaena sp.1 (FG=?) outcompeted other cyanobacteria probably due the increase in water transparency and decrease in ammonium-N. Finally, in phase III (rainy season) the decrease of water transparency triggered a recovery of shade-adapted cyanobacteria, but at this time mostly represented by Pseudanabaena limnetica $(\mathrm{FG}=\mathrm{S} 1)$. Phase III was also distinctive from the other ones by the highest Nitrate-N and phosphate$\mathrm{P}$ concentrations related to thermocline disruption, which favored an increase in total phytoplankton biomass recorded by the augment of green algae density $(\mathrm{FGs}=\mathrm{X} 1, \mathrm{~J}$ and $\mathrm{F})$. We concluded that the temporal dynamics of phytoplankton composition was associated to environmental changes in Castanhão Reservoir from 2012 to 2013, which were driven by seasonal climate variation from region (rainy/dry seasons), as well as, by the reduction in reservoir volume that resulted in the disruption of the thermocline, water mixing and an increase in inorganic $\mathrm{P}$ and $\mathrm{N}$.
\end{abstract}

Key words: Functional groups; cyanobacteria; green algae; nutrients; turbidity.

Received: August 2017. Accepted: November 2017.

\section{INTRODUCTION}

Phytoplankton is composed of a diverse community responsible for the primary productivity in water supply reservoirs. Due to their role as the basis of the food web as well as because of their short life cycles, the spatial and temporal dynamics of the phytoplankton community can provide important information about other biotic components and on general environmental conditions of an ecosystem (Reynolds, 2006). Additionally, water supply reservoirs are convenient environments to investigate the effects of environmental variables on phytoplankton structure due their highly dynamic conditions (Chellappa et al., 2009; Yang et al., 2017).
Seasonal fluctuations in rainfall alter the water volume stored by reservoirs as well as other environmental variables, such as mixing conditions, turbidity, oxygen and nutrients contents in the water column (Chaves et al., 2013; Mosley et al., 2015; Santos et al., 2017). These changes, in turn, lead to shifts in phytoplankton attributes (Chellappa et al., 2009; Câmara et al., 2015), which reinforce the use of this community to evaluate the environmental status of these aquatic ecosystems. For example, high concentrations of nutrients, high conductivity and increased phytoplankton biomass could be expected in reservoirs and lakes located in semi-arid regions with reduced water volume (Naselli-Flores, 2003; Bouvy et al., 2003; Mosley et al., 2012; Jirsa et al., 2013). On the other hand, since the reduction of water volume occurs along 
with intensification in sediment resuspension and turbidity, a negative impact on phytoplankton biomass could also be expected (Braga et al., 2015). Additionally, the dominance of few species, with particular concern for the dominance of potentially harmful cyanobacteria, often occurs in semi-arid regions under drought conditions (Bouvy et al., 1999; Brasil et al., 2016).

The phytoplankton classification into functional groups rather than only based on taxonomic affiliations has been often used as tool for environmental characterization of reservoirs (Silva et al., 2015; Rangel et al., 2016; Rodrigues et al., 2017). In the present study we have use Reynolds's functional groups (FGs), when the species with similar sensibilities, tolerances and ecologies affinities are placed together, being each FG selected by a set of environmental variables (habitat template) (Reynolds et al., 2002 reviewed by Padisák et al., 2009). This approach provides some advantages: i) it can be used to a clear characterization of the environment since the habitat template is known to each Reynolds's FG; and ii) it is of easy application because the FGs are already defined for a large amount of species and it does not require biovolume measurements to fitting each species into predetermined FGs, as other functional schemes need, such as that of Kruk et al. (2010). In this way, Reynolds et al. (2002) FG selection was the better adapted to our goal and the data set (species densities and total phytoplankton biomass), available for our studied reservoir. Other particular characteristic of Reynolds's functional scheme is that it requires the identification at the species level and sometimes genus level, an important information for characterizing water supply in reservoirs where potentially harmful cyanobacteria often occurs (Brasil et al., 2016). Additionally, Reynolds's FGs were previously used by Molisani et al. (2010) in the same studied reservoir, allowing a comparative approach.

In this sense, the objective of this work was to evaluate the effect of environmental changes on phytoplankton composition using taxonomic affiliations and Reynolds's functional groups in a large semi-arid reservoir during eighteen months of severe drought, when the water volume continually dropped due to rainfall shortage. Since droughts are increasing in frequency and severity in many regions such as in tropical semi-arid areas (Marengo et al., 2013; Marengo and Bernasconi, 2015), this study may give us clues to understanding the effect of climate change on phytoplankton of artificial reservoirs. These systems play fundamental roles in the Brazilian semi-arid due their multiple uses as drinking water supply and intensive fish-cage aquaculture sites (Cirilo, 2008; Molisani et al., 2015).

Additionally, the results obtained in the present study were compared with those found by Molisani et al. (2010) in the same reservoir, in order to evaluate possible shifts in the phytoplankton composition and biomass from the first years when the Castanhão Reservoir was completely filled $(2006 / 2007)$ to the period eight years later (2012/2013), when the reservoir suffered nearly 50\% of water reduction.

\section{METHODS}

\section{Study area}

The study was carried out in the Castanhão reservoir $\left(5.50^{\circ} \mathrm{S} 38.47^{\circ} \mathrm{W}\right)$ in the Middle Jaguaribe River watershed, which is located entirely within the semi-arid region in the State of Ceará, NE Brazil (Fig. 1). The total storage capacity of the reservoir is 6.7 billion $\mathrm{m}^{3}$, and the normal operating capacity is 4.45 billion $\mathrm{m}^{3}$. The reservoir reached its full capacity for the first time only in 2004 and covers an area of $325 \mathrm{~km}^{2}$ and is $48 \mathrm{~km}$ in length, with a depth exceeding $50 \mathrm{~m}$ in some areas (DNOCS, 2014). The Castanhão reservoir accounts for $97 \%$ of the total storage capacity from the Middle Jaguaribe River basin and is the largest reservoir in Ceará State. It serves multiple uses, including water supply for drinking water, agriculture and aquaculture (COGERH, 2011). The categories of the World Commission on Dams (2000) classify the Castanhão as a large reservoir.

The semi-arid climate of northeastern Brazil is characterized by annual rainfall means commonly ranging from 400 to $1000 \mathrm{~mm}$, with average of $756.5 \mathrm{~mm}$ during the past 80 years (FUNCEME, 2014). Rainfall occurs from January to June and is scarce from July to December.

Although the years of 2012 and 2013 have not been under El Niño influence, a phenomenon associated to lower rainfall in northeastern Brazil, these years were characterized as extreme drought due to the Atlantic dipole (Marengo et al., 2016). Some studies have reported that the heating of the North Atlantic waters, combined with a cooling of the South Atlantic waters, characterizing a positive Dipole, leads to a situation of descending movements of air over the Brazilian Northeast region, inhibiting the formation of clouds (Marengo et al., 2013; Nóbrega and Santiago 2014; Marengo et al., 2016). In fact, it was observed that in the years of 2012 and 2013, rainfall was only $302.3 \mathrm{~mm}_{\text {year }}{ }^{-1}$ and $656.5 \mathrm{~mm}_{\text {year }}{ }^{-1}$, respectively, significantly below the historical annual average (FUNCEME, 2014).

As a consequence of this period of intense drought during 2012/2013, the Castanhão reservoir showed a very distinctive situation from those observed until 2009, when the reservoir almost reached the limit of its total capacity storage, and even from 2011, when the reservoir volume was about $80 \%$ of its capacity (DNOCS, 2014). During the study period, the reservoir volume dropped progressively, reaching $72 \%, 65 \%, 55 \%$ and $50 \%$ of its total capacity in March 2012, August 2012, January 2013 and August 2013, respectively (DNOCS, 2014). 


\section{Sampling, environmental variables and chlorophyll $a$}

Sampling campaigns occurred in March and August 2012 and January and August 2013, covering 8 stations located throughout the reservoir (Fig. 1). The stations P1 and $\mathrm{P} 2$ corresponded to the inner zone, $\mathrm{P} 3$ and $\mathrm{P} 5$ to the middle zone, while P6, P7, P8 and P10 to the dam zone. Due to operational issues data from P1, P2 and P3 in March 2012, P1 in January/13 and P3 in August/13 were not collected.

Prior to water collection, major physical and chemical variables were measured in situ in sub-superficial waters ( 0.5 to $1.0 \mathrm{~m}$ depth): dissolved oxygen (YSI 556 probe, YSI Inc., Yellow Springs); water temperature, turbidity, electrical conductivity (Compact-CTD model AST D687; JFE Advantech Co., Ltd., Nishinomiya); pH (Portable 826 pH-meter; Metrohm AG, Herisau); and water transparency with a Secchi disk. Oxygen, water temperature, turbidity, electrical conductivity and $\mathrm{pH}$ were measured with an accuracy of $0.1 \mathrm{mg} \mathrm{L}^{-1}, 0.1^{\circ} \mathrm{C}, 0.1 \mathrm{NTU}, 1.0 \mu \mathrm{S}$ $\mathrm{cm}^{-1}$ and 0.1 , respectively.

Water samples collected from the subsurface $(1.0 \mathrm{~m})$ layer with a Van Dorn bottles were filtered in 47-mm-diameter AP40 glass fiber filters and analyzed for inorganic nutrients: nitrate-N (Braga et al., 2015), nitrite-N (Bend- schneider and Robinson, 1952), ammonium-N (Koroleff, 1970) and phosphate-P (Murphy and Rilley, 1962). Unfiltered samples were used to determine total phosphorus (TP) and total nitrogen (TN) (Valderrama, 1981). All nutrients were quantified in triplicate by visible spectrum spectrophotometry reaching detection limits of $1.0 \mu \mathrm{g} \mathrm{L}^{-1}, 10$ $\mu \mathrm{g} \mathrm{L}^{-1}, 0.1 \mu \mathrm{g} \mathrm{L}^{-1}, 1.4 \mu \mathrm{g} \mathrm{L}^{-1}, 0.1 \mathrm{mg} \mathrm{L}^{-1}$ and $5.0 \mu \mathrm{g} \mathrm{L}^{-1}$ for phosphate-P, nitrate- $\mathrm{N}$, nitrite- $\mathrm{N}$, ammonium- $\mathrm{N}, \mathrm{TN}$ and TP, respectively. The chlorophyll $a$ concentrations were used as an estimative of total phytoplankton biomass in each sample and were obtained in a spectrophotometer according to the ISO 10260 (1992) protocol. For chlorophyll $a$ analysis the samples were filtered immediately after sampling in a field lab through 47-mm-diameter AP40 glass fiber filters. More detailed field procedures and analytical methods were described previously by Santos et al. (2017).

\section{Phytoplankton analysis}

Phytoplankton samples were taken from the subsurface layer with a Van Dorn bottle concomitantly with those for nutrients and were immediately fixed with Transeau solution (ratio 1:1). The quantification and identification of phytoplankton organisms were performed ac-

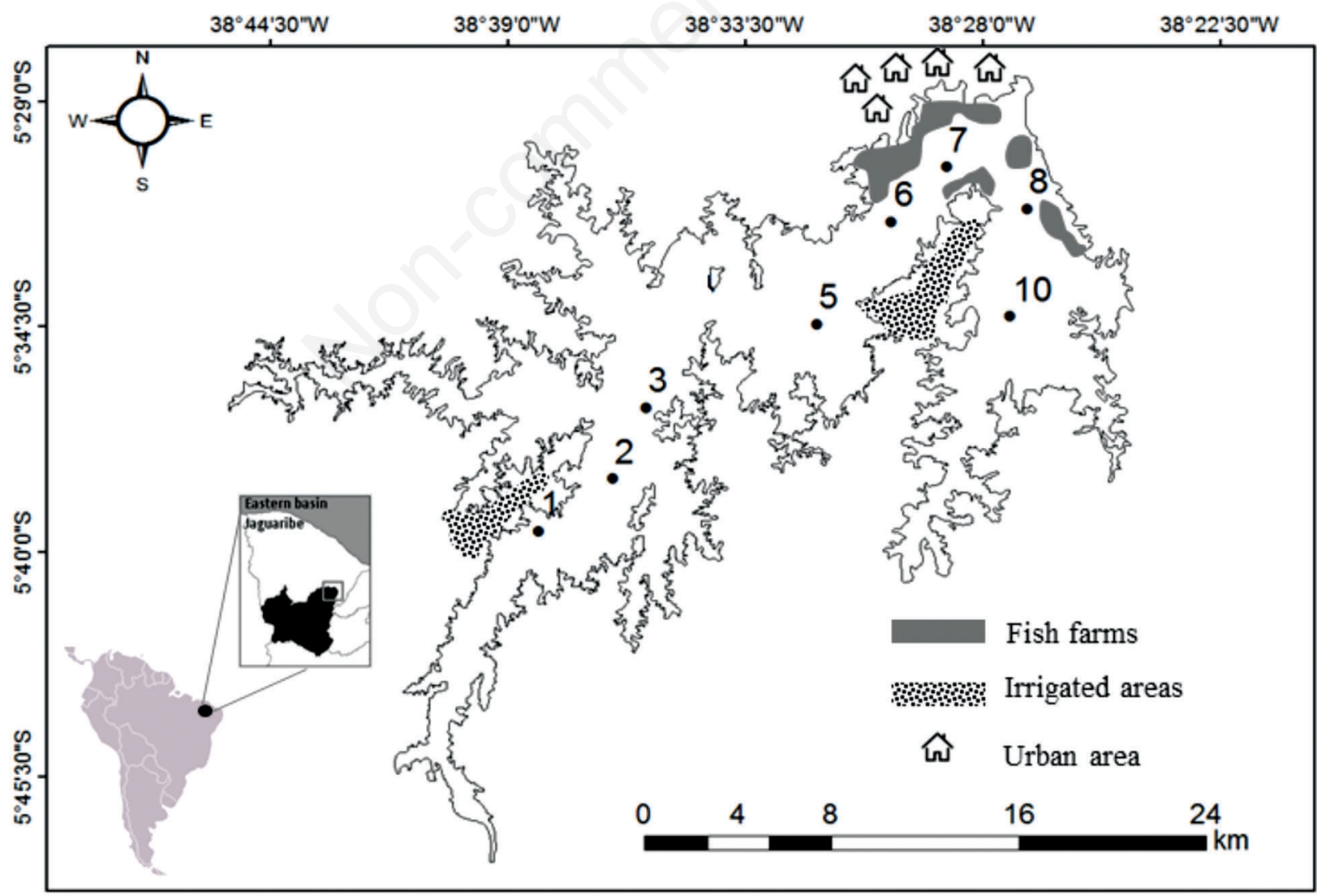

Fig. 1. Study area and location of sampling stations in the Castanhão reservoir, NE Brazil. 
cording to the Utermöhl (1958) method in an inverted microscope equipped with phase-contrast (Olympus CK2) (Edler and Elbrächter, 2010). The phase-contrast was used to improve the quantification and identification of slender cyanobacteria. The volume of sedimentation chambers was of 2 or $5 \mathrm{~mL}$, depending on the organisms' concentration and sedimentation time ranged from 24 to 48 hours. The counting was standardized to obtain at least 100 organisms (cells, colonies, filaments and trichomes) of the dominant taxa, with the standard error estimated to be $20 \%$ and the confidence limit of $95 \%$ (Edler and Elbrächter, 2010).

During the counting procedure the organisms were quantified and identified concomitantly at 400x magnification. However, to help in qualitative analysis, at the time of counting, the organisms were photographed and subsequently measured and analyzed according their morphology for identification at the lowest possible taxonomic level using the bibliography cited thereafter. The images were processed using Axio Vision Rel. 4.7 software which allowed the accurate measurement of the organisms, even those slender cyanobacteria with a diameter of about $1.0 \mu \mathrm{m}$. When necessary, organisms were also observed under 1000x magnification. In this step, it was possible to identify four pairs of species that were not separated during the counting procedure, due their large morphology similarity. They were i) Planktolyngbya minor and Pl. limnetica; ii) Pseudanabaena catenata and Ps. papillaterminata; iii) Cylindrospermopsis sp. and $C$. raciborskii (on coiled morphotypes); iv) Synedra acus and Fragilaria delicatissima. Therefore, though in qualitative analysis these species have been discriminated, in statistical analysis these four pairs of species were considered as four taxa because they were previously counted together. It is important to emphasize that, as each pair of species was classified in the same Reynolds's FG, no bias was introduced in data interpretation.

The identification was based on specific bibliography (books and articles) for each phytoplankton group (Komárek and Anagnostidis, 2000; Komárek, 2001; Brassac and Ludwig, 2003; Cronberg and Komárek, 2004; Komárek and Anagnostidis, 2005; Bicudo and Menezes, 2006; Komárek, 2013; McGregor, 2013; and references therein). The identified taxa were assembled into functional groups, using the criteria established in Reynolds et al. (2002) and reviewed by Padisák et al. (2009).

\section{Data analysis}

\section{Relative abundance and frequency of occurrence}

In order to evaluate the structure of the phytoplankton community, the following indicators were used: density expressed in organisms $\mathrm{L}^{-1}$ (org L $\mathrm{L}^{-1}$ ), relative abundance (RA) and frequency of occurrence (F) expressed as a per- centage. The relative abundances (RA) (\%) of each taxonomic class, taxa or functional group were calculated based on the density of each one in relation to total density of organisms in the sample. In turn, the frequencies of occurrence of each taxon were calculated based on the numbers of samples where each taxon occurred divided by the total number of total samples. Regarding the frequency of occurrence, each taxon could be classified as: Rare ( $\mathrm{F} \leq$ $10 \%)$; Common $(10 \%<\mathrm{F} \leq 50 \%)$ or Constant $(\mathrm{F}>50 \%)$.

\section{Statistical analysis}

Contents of chlorophyll $a$ and other environmental variables (except $\mathrm{pH})$ were transformed by $\log (\mathrm{x}+1)$ before all multivariate analysis. For phytoplankton densities (total and of each taxon), data were transformed by fourth root prior to statistical analysis.

The differences among the reservoir zones (inner, middle and dam) relative to environmental variables, total phytoplankton density and chlorophyll $a$ were analyzed using one-way analysis of variance (ANOVA) followed by Tukey's honestly significant different test (T-HSD) at $\mathrm{P}<0.05$ level of probability. In turn, to test the hypothesis of significant differences among the reservoir zones relative to total phytoplankton composition, we used a Permutational Multivariate Analysis of Variance based on Bray-Curtis similarity (PERMANOVA, $\mathrm{P}<0.05$ ).

Bray-Curtis similarity based on densities of all phytoplankton taxa was also used to access the degree of similarity of phytoplankton community among samples. Cluster analysis based on the Bray-Curtis similarity was performed using UPGMA, and the significance of groups was tested with the Similarity Profile test (SIMPROF). A similarity percentage analysis (SIMPER) was applied to obtain the contribution of each taxa in percent terms to the similarity within each group. The 'characterizing taxa' was defined as those taxa that most contributed to the similarity within each group using a cut-off of $90 \%$. The significance level for SIMPROF and SIMPER was $\mathrm{P}<0.05$.

The SIMPROF results showed that samples could be divided in three significant groups relative to total phytoplankton composition $(\mathrm{P}<0.05)$. In order to test the hypothesis of differences among these three sample groups for environmental variables, chlorophyll $a$ and total phytoplankton density, ANOVA was used followed by Tukey's honestly significant different test $(\mathrm{P}<0.05)$.

Redundancy analysis (RDA), a constrained ordination method, was used to examine the relationships between the environmental variables and phytoplankton community and to select the variables that best described the temporal variability of phytoplankton structure. Firstly, two RDA models were performed in order to test the efficiency of the top 'characterizing taxa' to summarize the overall temporal variability of phytoplankton structure and their correlations with environmental variables: one 
using biotic data of all 102 taxa (response matrix 1) found along the survey; and another using only the top nineteen 'characterizing taxa' (response matrix 2) defined by the SIMPER (cut-off 90\%). The length of the first axis $(<3.0)$ of Detrended Correspondence Analysis (DCA) of response matrices data supported the use of RDA.

For both response matrices 1 and 2, the same procedures were adopted to reach the final RDA and to access the relationships between environmental variables (predictor matrix) and phytoplankton structure (response matrix). Firstly, a preliminary RDA was performed with all available environmental variables: Secchi depth (Secchi), turbidity, $\mathrm{pH}$, Temperature, Conductivity, Dissolved Oxygen, Total Phosphorous, Total Nitrogen, phosphate-P, nitrate-N, nitrite-N and ammonium-N. Only the significant variables $(\mathrm{P}<0.05)$ were retained in the second RDA. In order to know the collinearity among the explanatory variables, we calculated the variation inflation factor (VIF) of each one. The VIF $>10$ indicates that a variable is strongly dependent on others and therefore does not have independent information (Oksanen et al., 2015). Only variables with VIF $<10$ were used in the second RDA model. We tested the marginal significance of the remaining variables by 999 permutations, and only those with significance were used in final RDA. The significance of the first two axis and of the final RDA models were tested by 999 permutations. The adjusted $\mathrm{R}^{2}$ values were computed to obtain the explanatory power of the final RDAs.

As the same results were found for RDAs using the response matrix 1, based on biotic data of all 102 taxa (data not shown), and the response matrix 2, based on the top nineteen 'characterizing taxa', only the last one is shown due its higher power to summarize the variability of phytoplankton composition in the Castanhão reservoir throughout the survey.

The ANOVA and T-HSD tests were performed using the software Statistica ${ }^{\circledR} 7.0$ (Statsoft Inc., Tulsa, OK, USA). The Bray-Curtis similarity followed by cluster analysis, the SIMPROF test and SIMPER procedure were carried out using the software PRIMER 6.0 (Plymouth Marine Laboratory). PERMANOVA, DCA and RDA analyses were done using the vegan package in $\mathrm{R}$ software (Oksanen et al., 2015).

\section{RESULTS}

A total of 102 taxa were identified, distributed among the classes Cyanophyceae (cyanobacteria) (34), Chlorophyceae (green algae) (42), Bacillariophyceae (diatoms) (18), Zygnemaphyceae (4) and Euglenophyceae (4), besides one unidentified phytoflagellate taxon. Within this total set of 102 taxa, we discriminated 18 functional groups, being Cyanophyceae in seven codons; MP, S1, L, LM, Lo, $\mathrm{S}_{\mathrm{N}}$ and H1, Bacillariophyceae in six; P, B, D, MP, C and B,
Chlorophyceae in four; P, X1, F and J, Zygnemaphyceae in two; N e NA and Euglenophyceae in one codon; W2. Furthermore, 26 taxa from the total data set were not classified to any functional group described by Reynolds et al. (2002) and Padisák et al. (2009) either because their identification did not occur at the taxonomic level of species or genera or because they have not yet been included within the associations described by those authors. Among the most representative taxa not assigned to any functional group, we highlight Pseudanabaena papillaterminata, Pseudanabaena cf. biceps, Pseudanabaena sp.1 and Myxobaktron sp. This reinforces the fact that the categorization of phytoplankton into Reynolds's functional groups, especially taking into account tropical ecosystems, needs to be revised aiming the inclusion of new species within the previously described groups as well as with the proposition of new functional groups. For this, the ecology of each species still needs to be better understood.

Therefore, taking into consideration the recommendations provided by Padisák et al. (2009) we classified PS. cf. biceps and Ps. papillaterminata on functional group MP, which included periphytic or epilithic species occasionally found in plankton samples. Komárek and Anagnostidis (2005) described PS. papillaterminata as a benthonic species. In turn, Ps. cf. biceps is found mainly attached to substrate (Komárek and Anagnostidis, 2005; Douma et al., 2009; Klemenčič et al., 2010).

For Myxobaktron sp. we propose its classification as $\mathrm{X} 1$ codon, because it reached the better performance along with small green algae of similar morphology belonging to X1 codon (see Discussion section). However, as Myxobaktron is a genus poorly cited in limnological studies and information about its autoecology is scarce, we prefer to assign it as $\mathrm{FG}=\mathrm{X} 1$ (?). In the case of Pseudanabaena sp.1, a slender genus of cyanobacteria, which the classification on Reynolds's FG depends on species, it was not proper to assign it to any functional group because it reached maximum density in a distinct moment from the other 'characterizing taxa' of similar morphology. Additionally, due to their close association with Secchi depth, we have avoided its classification in MP or S1, typical codons from turbid environments (Padisák et al., 2009). Therefore, from the list of 102 taxa, where 26 of them were not previously classified to any Reynolds's FGs, 23 taxa remained as unsigned.

\section{Spatial variability}

The results from abiotic variables characterizing the inner, middle and dam zones during the sampling period are summarized in Supplementary Tab. 1. Except for turbidity, no significant differences were found between the zones (ANOVA, $\mathrm{P}>0.05$ ). The turbidity values in the inner zone were significantly higher than those found in middle and dam zones (ANOVA, T-HSD, $\mathrm{P}<0.05$ ). In the inner 
zone, the lowest Secchi-disk transparency values were also observed. In all three zones, alkaline $\mathrm{pH}$ and highwater temperature $\left(>27.0^{\circ} \mathrm{C}\right)$ were observed, as well as, high levels of oxygen $\left(>6.0 \mathrm{mg} \mathrm{L}^{-1}\right)$ and conductivity $\left(>300 \mu \mathrm{S} \mathrm{cm}^{-1}\right)$. On the other hand, the levels of inorganic nutrients were generally low, ranging from non-detectable to maximum concentrations of $11.2 \mu \mathrm{g} \mathrm{L}^{-1}, 44.6 \mu \mathrm{g} \mathrm{L}^{-1}$, $2.5 \mu \mathrm{g} \mathrm{L}^{-1}$ and $132.4 \mu \mathrm{g} \mathrm{L}^{-1}$ for phosphate-P, nitrate-N, nitrite-N and ammonium-N, respectively. The TN and TP concentrations ranged from low to intermediated values in each zone, with average values of these nutrients below $30 \mu \mathrm{g} \mathrm{L}^{-1}(\mathrm{TP})$ and $620 \mu \mathrm{g} \mathrm{L}^{-1}(\mathrm{TN})$.

Average phytoplankton densities were $4.0( \pm 3.0) 10^{6}$ organisms $\mathrm{L}^{-1}, 6.0( \pm 4.0) \times 10^{6}$ organisms $\mathrm{L}^{-1}$ and 10 $( \pm 8.0) \times 10^{6}$ organisms $\mathrm{L}^{-1}$ at inner, middle and dam zones, respectively. Although the phytoplankton densities have increased toward the dam zone, no significant differences were found between the three reservoir zones (ANOVA, $\mathrm{P}>0.05)$. Similarly, the total phytoplankton biomass (chlorophyll $a$ ) increased from the inner to the dam zone, with average values of $2.9 \pm 0.5 \mu \mathrm{g} \mathrm{L}^{-1}, 4.5 \pm 0.7 \mu \mathrm{g} \mathrm{L}^{-1}$ and $5.0 \pm 2.1 \mu \mathrm{g} \mathrm{L}^{-1}$ at the inner, middle and dam zones, respectively. A significant difference was found between the inner and dam zone (ANOVA, T-HSD, $\mathrm{P}<0.05$ ), but not between the middle and dam zone (ANOVA, T-HSD, $\mathrm{P}>0.05$ ).
In all three zones of the reservoir the cyanobacteria were dominant with a relative abundance above $80 \%$, followed by green algae and diatoms with relative abundances ranging from 5 to $10 \%$ in each zone. The most abundant functional group in all three zones was S1 (Fig. 2), represented mainly by the cyanobacteria Pseudanabaena limnetica and Planktolyngbya limnetica/Pl. minor. The third more abundant taxon was the cyanobacteria Pseudanabaena sp. $1(\mathrm{FG}=$ ?), not assigned to any functional group (Fig. 2). Thus, the phytoplankton composition throughout the reservoir was very constant and no significant differences were found among the zones by PERMANOVA test ( $\mathrm{F}$ model $=1.4061 ; \mathrm{r}^{2}=0.05325 ; \mathrm{P}=0.234 ; 999$ permutations).

\section{Temporal variability}

The cluster analysis based on the densities of the 102 phytoplankton taxa is presented in Fig. 3. In this Figure, the formation of three significant groups can observed (SIMPROF, $\mathrm{P}<0.05$ ), showing a clear tendency to temporal clustering of samples in three phases/groups: phase I including all samples from March/12; phase II formed by samples from August/2012 and January/2013, plus one sample from August/2013 (P1); and phase III including all samples from August/2013 (except for P1).

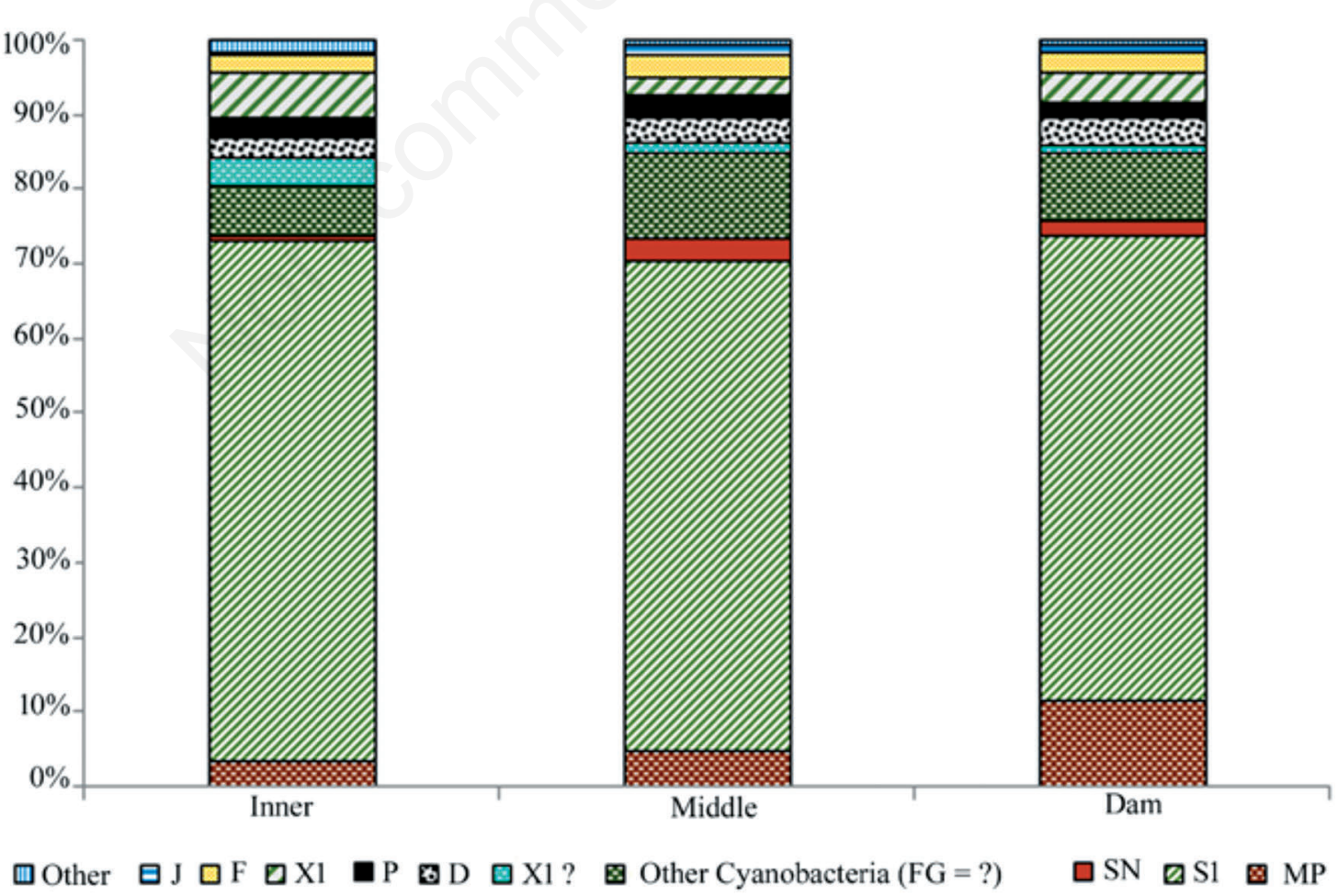

Fig. 2. Mean relative abundance (\%) of the main phytoplankton functional groups for the three spatial zones from Castanhão Reservoir during the sampling period. Codon X1? only included Myxobaktron sp., while Other Cyanobacteria (FG=?) refers only to Pseudanabaena sp. 1. 
Supplementary Tab. 2 summarizes the results of abiotic variables of the three temporal phases suggested by cluster analysis. No significant differences were found for turbidity, dissolved oxygen, $\mathrm{pH}$, nitrite- $\mathrm{N}, \mathrm{TP}$ and TN among the phases (ANOVA, $\mathrm{P}>0.05$ ). In turn, the water temperature was significantly different among the phases, reaching higher values in temporal phases I and III, corresponding to the rainy period (ANOVA, T-HSD, $\mathrm{P}<0.05$ ). The higher Secchi-disk depth was found in phase II (ANOVA, T-HSD, $\mathrm{P}<0.05$ ), while the higher conductivity and nitrate-N were observed in phase III (ANOVA, T-HSD, $\mathrm{P}<0.05)$. Phase I was distinctive from the others by the lowest phosphate-P concentrations (ANOVA, T-HSD, $\mathrm{P}<0.05$ ). Phase II was also distinctive from phase I by the lowest ammonium-N concentrations (ANOVA, T-HSD, $\mathrm{P}<0.05$ ).

A list of the major contributors ('characterizing taxa') to similarity within each group/phase according to the SIMPER procedure (cut-off $90 \%$ ) and their frequency of occurrence during the survey are presented in Tab. 1. Tab. 2 summarizes the percentage contribution of the major contributors, but with a cut-off of $70 \%$, to the average similarity within each group/phase. In all phases the cyanobacteria were the dominant class, followed by diatoms in phase II and green algae in phase III (Tab. 2).
The mean relative abundance (\%) of the main phytoplankton functional groups for the phases/groups during the sampling period are presented in Fig. 4. Phase I is clearly distinct from phase II by the dominance of the functional group S1, represented mainly by cyanobacteria Planktolyngbya limnetica/Pl. minor with relative abundance of $62.3 \%$ along with Pseudanabaena limnetica (RA $=25 \%$ ). Other important functional groups in phase I were MP represented mainly by cyanobacteria $P$ s. catenata/Ps. papillaterminata $(\mathrm{RA}=7.5 \%)$ and $\mathrm{S}_{\mathrm{N}}$ represented by Cylindrospermopsis sp./C. raciborskii $(\mathrm{RA}=1.7 \%)$.

In phase II the taxa present in phase I decreased in density and were outcompeted mainly by cyanobacteria Pseudanabaena sp.1 ( $\mathrm{FG}=$ ?) $(\mathrm{RA}=36.2 \%)$. Pl. limnetica/Pl. minor (S1) continued to be an important cyanobacteria in phase II with relative abundance of $21.3 \%$, followed by Ps. cf. biceps (MP) (RA=8.4\%), Cylindrospermopsis sp./C. raciborskii $\left(\mathrm{S}_{\mathrm{N}}\right)(\mathrm{RA}=3.9 \%)$ and Myxobaktron sp. (X1?) (RA=2.6\%). Despite in phase II the Cyanophyceae have also been the dominant class, an increase in Bacillariophyceae was observed, mainly due to Nitzschia sp. (D) (RA=5.6\%) and Aulacoseira granulata var. granulata $(\mathrm{P})(\mathrm{RA}=3.5 \%)$ (Fig. 4).

Finally, in phase III the functional group S1 increased again in density and relative abundance, mainly due to the

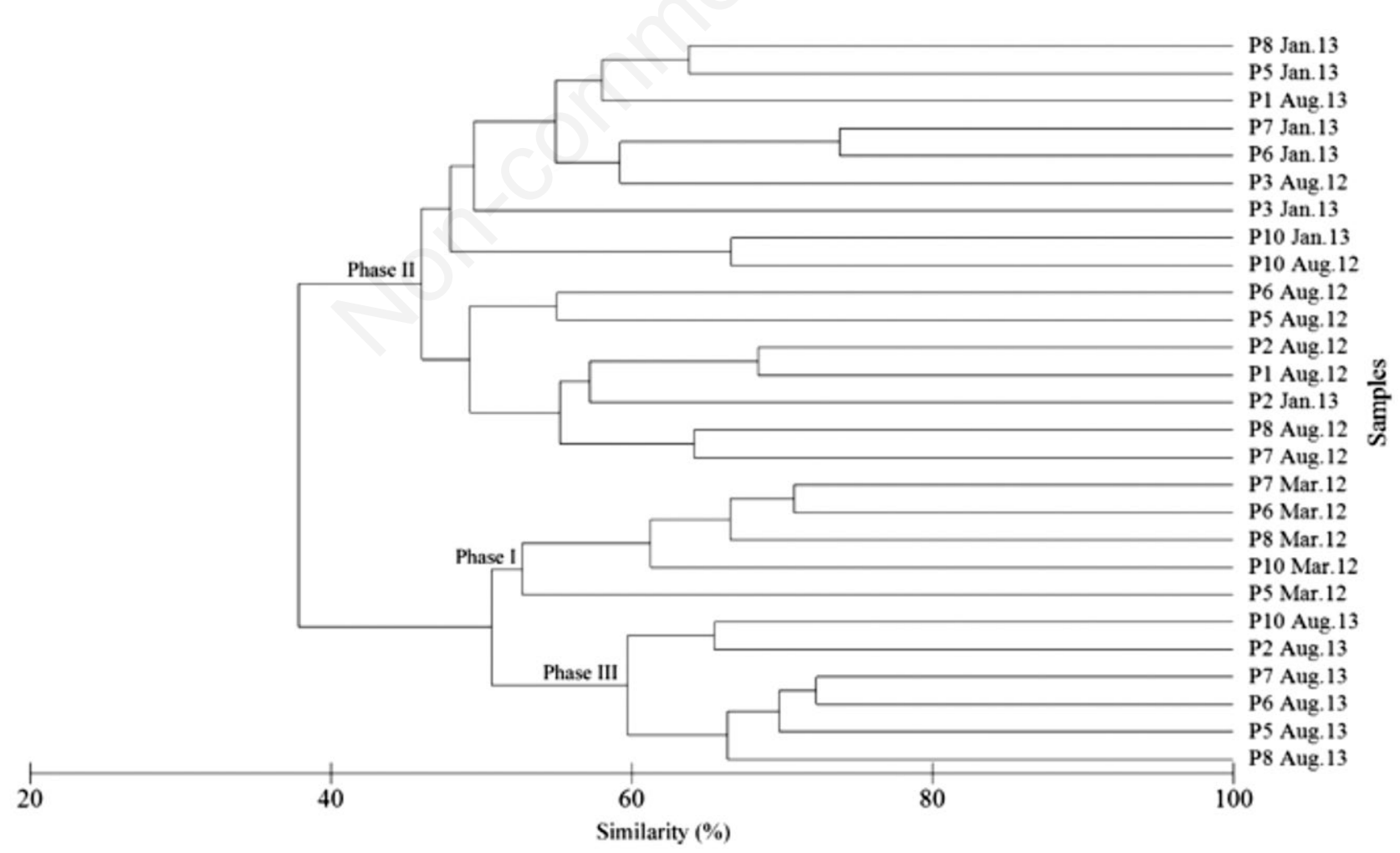

Fig. 3. Cluster analysis based on the density of the 102 phytoplankton taxa. Temporal Groups/Phases I, II and III were significant according to the SIMPROF test $(\mathrm{P}<0.05)$. 
Tab. 1. Major contributors ('characterizing taxa') to similarity within each group in the clustering analysis according to the SIMPER procedure (cut-off 90\%), functional group, life form and frequency of occurrence. Pl. minor and Pl. limnetica; Ps. catenata and Ps. papillaterminata; Cylindrospermopsis sp. and C. raciborskii; S. acus and F. delicatissima weren't identified individually during counting due to strong similarity, therefore counts refer to each pair of species.

$\begin{array}{lcc}\text { Characterizing taxa } & \text { Functional } & \text { Frequence of } \\ \text { group }{ }^{1} & \text { Life form }^{2} & \text { occurence }\end{array}$

\section{Cyanophyceae}

Planktolyngbya minor (Geitler \& Ruttner) Komárek \& Cronberg / Planktolyngbya limnetica

(Lemmermann) Komárková-Legnerová \& Cronberg

Pseudanabaena limnetica (Lemmermann) Komárek

Pseudanabaena catenata Lauterborn / Pseudanabaena papillaterminata (Kiselev) Kukk

Cylindrospermopsis sp. / Cylindrospermopsis raciborskii (Woloszynska) Seenayya \& Subba Raju

Pseudanabaena sp. 1

Pseudanabaena $\mathrm{cf}$. biceps Böcher

Myxobaktron sp.

\section{Chlorophyceae}

Schroederia setigera (Schröder) Lemmermann

Monoraphidium circinale (Nygaard) Nygaard

Ankyra judayi (G.M.Smith) Fott

Monoraphidium minutum (Nägeli) Komárková-Legnerová

Oocystis lacustris Chodat

Elakatothrix sp.

Micractinium pusillum Fresenius

Golenkinia sp.

$\begin{array}{ccc}\text { S1 } & \text { Fi } & \text { Constant } \\ \text { S1 } & \mathrm{Fi} & \text { Constant } \\ \text { MP } & \mathrm{Fi} & \text { Common } \\ \mathrm{S}_{\mathrm{N}} & \mathrm{Fi} & \text { Common } \\ ? & \mathrm{Fi} & \text { Constant } \\ \text { MP } & \mathrm{Fi} & \text { Constant } \\ \text { X1 ? } & \mathrm{UNF} & \text { Constant }\end{array}$

\section{Bacillariophyceae}

Nitzschia sp. $(12-25 \mu \mathrm{m})$

Synedra acus Kützing / Fragilaria delicatissima (W. Smith) Lange-Bertalot

Aulacoseira granulata (Ehrenberg) Simonsen var. granulata

Aulacoseira granulata (Ehrenberg) Simonsen var. angustissima

\begin{tabular}{ccc} 
X1 & UNF & Common \\
X1 & UNF & Common \\
X1 & UNF & Common \\
X1 & UNF & Constant \\
F & CNF & Constant \\
F & CNF & Common \\
F & CNF & Constant \\
J & UNF & Constant \\
\hline & & \\
D & UNF & Constant \\
D & UNF & Common \\
P & CNF & Constant \\
P & CNF & Constant
\end{tabular}

${ }^{1}$ Functional group: defined according to Reynolds et al. (2002) and Padisák et al. (2009). (? - unidentified functional group). ${ }^{2}$ Life form: unicellular non-flagellated (UNF), colonial non-flagellated (including coenobia) (CNF) and filaments (Fi). ${ }^{3}$ Frequency of occurrence (\%): rare (F $\left.\leq 10 \%\right)$, common $(10 \%<F \leq 50 \%)$ and constant $(F>50 \%)$ based on the occurrence related to the total number of samples (? - unidentified functional group).

Tab. 2. Total phytoplankton biomass (mean \pm standard deviation), Total phytoplankton density (mean standard \pm deviation), Relative abundance of main taxonomic classes, and major phytoplankton taxa to the average similarity within each group/phase (cut-off 70\%). Percentage contribution of each taxa to the similarity within each group are presented in parenthesis.

\begin{tabular}{|c|c|c|c|}
\hline & Group/Phase I & Group/Phase II & Group/Phase III \\
\hline Average similarity according cluster analysis & $59.9 \%$ & $50.1 \%$ & $61.6 \%$ \\
\hline Total phytoplankton biomass (Chlorophyll a) $\left(\mu \mathrm{g} \mathrm{L}^{-1}\right)$ & $3.97 \pm 1.1^{\mathrm{a}}$ & $4.05 \pm 1.21^{\mathrm{a}}$ & $6 \pm 3^{\mathrm{a}}$ \\
\hline Total phytoplankton density $\left(10^{6}\right.$ organisms $\left.\mathrm{L}^{-1}\right)$ & $20 \pm 5^{\mathrm{a}}$ & $4 \pm 3^{\mathrm{b}}$ & $10 \pm 3^{\mathrm{a}}$ \\
\hline Relative abundance of main taxonomic classes & $\begin{array}{l}\text { Cyanophyceae }(96.4 \%), \\
\text { Chlorophyceae }(2 \%), \\
\text { Bacillariophyceae }(1.6 \%)\end{array}$ & $\begin{array}{l}\text { Cyanophyceae }(80.3 \%), \\
\text { Bacillariophyceae }(12 \%) \text {, } \\
\text { Chlorophyceae }(7.5 \%)\end{array}$ & $\begin{array}{l}\text { Cyanophyceae }(75 \%), \\
\text { Chlorophyceae }(17.6 \%), \\
\text { Bacillariophyceae }(6.8 \%)\end{array}$ \\
\hline $\begin{array}{l}\text { Major contributors to similarity within each assemblage } \\
\text { (by SIMPER procedure, cut-off } 70 \% \text { ) }\end{array}$ & $\begin{array}{l}\text { Planktolyngbya minor and } \\
\text { Pl. limnetica }(\mathrm{S} 1)(28.7 \%) ; \\
\text { Pseudanabaena limnetica }(\mathrm{S} 1) \\
(21.7 \%) ; \text { Ps. catenata } \text { and } \\
\text { Ps. papillaterminata }(\mathrm{MP}) \\
(14.4 \%) ; \text { Cylindrospermopsis } \\
\text { sp. and C. raciborskii }\left(\mathrm{S}_{\mathrm{N}}\right) \\
(5.8 \%)\end{array}$ & $\begin{array}{l}\text { Pseudanabaena sp.1 (FG ?) } \\
(18.9 \%) ; \text { Aulacoseira granulata } \\
\text { var. granulata }(\mathrm{P})(11.6 \%) ; \\
\text { Pl. minor and Pl. limnetica } \\
(\mathrm{S} 1)(10.5 \%) ; \text { Ps. cf. biceps } \\
(\mathrm{MP})(10.1 \%) ; \text { A. granulata } \\
\text { var. angustissima }(\mathrm{P})(8.5 \%) ; \\
\text { Nitzschia } \mathrm{sp} .(12-25 \mu \mathrm{m})(\mathrm{D}) \\
(6.9 \%) ; \text { Myxobaktron } \mathrm{sp} . \\
(\mathrm{X} 1 \text { ?) }(6.5 \%) .\end{array}$ & $\begin{array}{l}\text { Ps. limnetica }(\mathrm{S} 1)(16.53 \%) ; \\
\text { aPl. minor and Pl. limnetica } \\
(\mathrm{S} 1)(9.8 \%) ; \text { Nitzschia sp. } \\
(12-25 \mu \mathrm{m})(\mathrm{D})(9.3 \%) ; \\
\text { Micractinium pusillum }(\mathrm{F}) \\
(8.1 \%) ; \text { Ps. catenata and } \\
\text { Ps. papillaterminata }(\mathrm{MP}) \\
(7.7 \%) ; \text { Monoraphidium } \\
\text { minutum }(\mathrm{X} 1)(7.7 \%) ; \\
\text { Myxobaktron sp. }(\mathrm{X} 1 \text { ?) }(5.7 \%) ; \\
\text { Ankyra judayi }(\mathrm{X} 1)(4.7 \%) ; \\
\text { A. granulata var. granulata }(\mathrm{P}) \\
(4.7 \%) .\end{array}$ \\
\hline
\end{tabular}


cyanobacteria Ps. limnetica $(\mathrm{RA}=40.3 \%)$ and $P$ l. limnet$i c a / P l$. minor $(\mathrm{RA}=14.4 \%$ ). These taxa were followed by cyanobacteria Ps. catenata/Ps. papillaterminata (MP) (RA=7.4\%) and Ps. cf. biceps (MP) (RA=4.6\%). Notwithstanding, different from phase I, other functional groups, such as F (mainly due the green algae Micractinium pusillum, RA $=5.9 \%$ ), D (mainly due the diatom Nitzschia sp. $\mathrm{RA}=4.9 \%$ ) and $\mathrm{X} 1$ (mainly due the green algae Ankyra judayi, RA=2.5\%; and Monoraphidium minutum, $\mathrm{RA}=2.4 \%$ ) were also well represented in phase III (Fig. 4).

Phase II was distinct from phases I and III by lower total phytoplankton density (ANOVA, T-HSD, $\mathrm{P}<0.05$ ), but no significant difference was observed between phases I and III (ANOVA, T-HSD, P >0.05, Tab. 2). In relation to the total phytoplankton biomass (chlorophyll $a$ ), no significant differences were found among the phases (ANOVA, $\mathrm{P}>0.05$, Tab. 2), though the average have increased progressively from phase I to III.

\section{Redundancy analysis}

The RDA performed with nineteen top 'characterizing taxa' defined by the SIMPER procedure (cut-off $90 \%$ ), as presented in Supplementary Tab. 3, included Secchi depth $(\mathrm{P}=0.015)$, ammonium- $\mathrm{N}(\mathrm{P}=0.010)$, nitrate- $\mathrm{N}(\mathrm{P}=0.010)$ and phosphate- $\mathrm{P}(\mathrm{P}=0.005)$, which showed significant marginal effects and VIF $<10$ (Fig. 5).

The RDA model selected for these four variables was significant $(\mathrm{F}=6.6, \mathrm{df}=4, \mathrm{P}=0.001)$ with an explanatory power of $46.3 \%\left(\mathrm{R}^{2}=0.545\right.$; adjusted $\left.\mathrm{R}^{2}=0.463\right)$. The first RDA axis was significant $(\mathrm{P}=0.001)$ and mainly positively correlated to ammonium-N (0.5961) and negatively to Secchi depth (-0.7733). Axis 2 was also significant $(\mathrm{P}=0.001)$ and negatively correlated with nitrate- $\mathrm{N}$ $(-0.4310)$ and phosphate-P (-0.8657).

The first axis (RDA1) separated in the positive side the sampling units from phases I and III, characterized by the highest concentration of ammonium- $\mathrm{N}$ and nitrate- $\mathrm{N}$, respectively (Fig. 5). The sampling units from phase I were also distinctive from the others by the lowest phosphate-P concentrations, which were below the detection limits of the analytical method (see Supplementary Tab. 2). Thus, the lowest phosphate-P in phase I contributed to the best performance of Pl. limnetica/Pl. minor (S1) while the highest ammonium-N favored Ps. catenata/Ps. papillaterminata (MP).

On the other hand, in the negative side of axis 1 , the sampling units from phase II were separated and characterized by the highest Secchi depth, lowest inorganic nitrogen and an increase in phosphate-P concentrations.

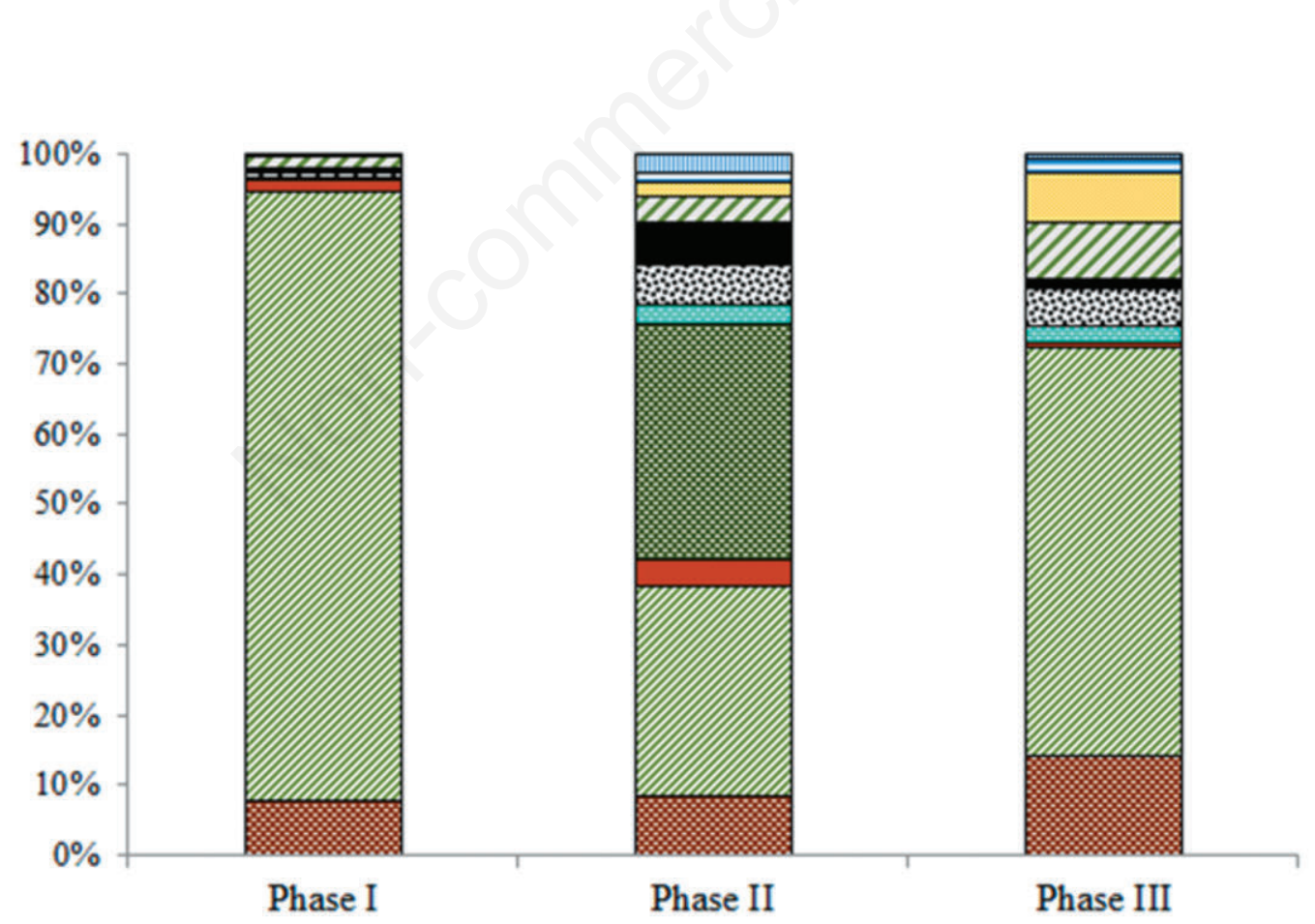

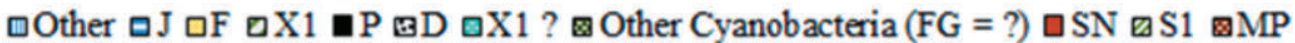

Fig. 4. Mean relative abundance (\%) of the main phytoplankton functional groups for the temporal phases/groups defined by cluster analysis during the sampling period. In codon X1? was only included Myxobaktron sp., while Other Cyanobacteria (FG=?) refers only to Pseudanabaena sp. 1. 
This decline in inorganic nitrogen from phase I to phase II, plus an increase in phosphate-P, could be associated to the best performance of Pseudanabaena sp.1 (FG ?) over other cyanobacteria, though a decrease in the total phytoplankton density have occurred, which also leaded to high Secchi depth.

Finally, in phase III an increase in inorganic nitrogen, mainly nitrate-N, was observed. This condition can have triggered a recovery of cyanobacteria from functional group S1, but at this time mostly represented by Ps. limnetica (S1), which was also associated to low Secchi depth. In phase III, various green algae from functional groups $\mathrm{X} 1, \mathrm{~J}$ and $\mathrm{F}$ were also favored by increased nitrate$\mathrm{N}$, but also phosphate-P.

Other important information shown by the RDA model for some species with little known autoecology were the close association of Pseudanabaena cf. biceps (MP) with the highest concentrations of phosphate-P; and Myxobaktron sp. (X1 ?) with highest nitrate-N and phosphate-P concentrations.

\section{DISCUSSION}

The analysis of the results of spatial and temporal dynamics of the phytoplankton community in the Castanhão reservoir along the years of 2012 and 2013, when the volume of the reservoir progressively decreased from $70 \%$ to $50 \%$ (Santos et al., 2017), showed a tendency of temporal rather than spatial variation across the zones. In general, the study period could be divided in three phases based on the phytoplankton structure. Phase I included all samples

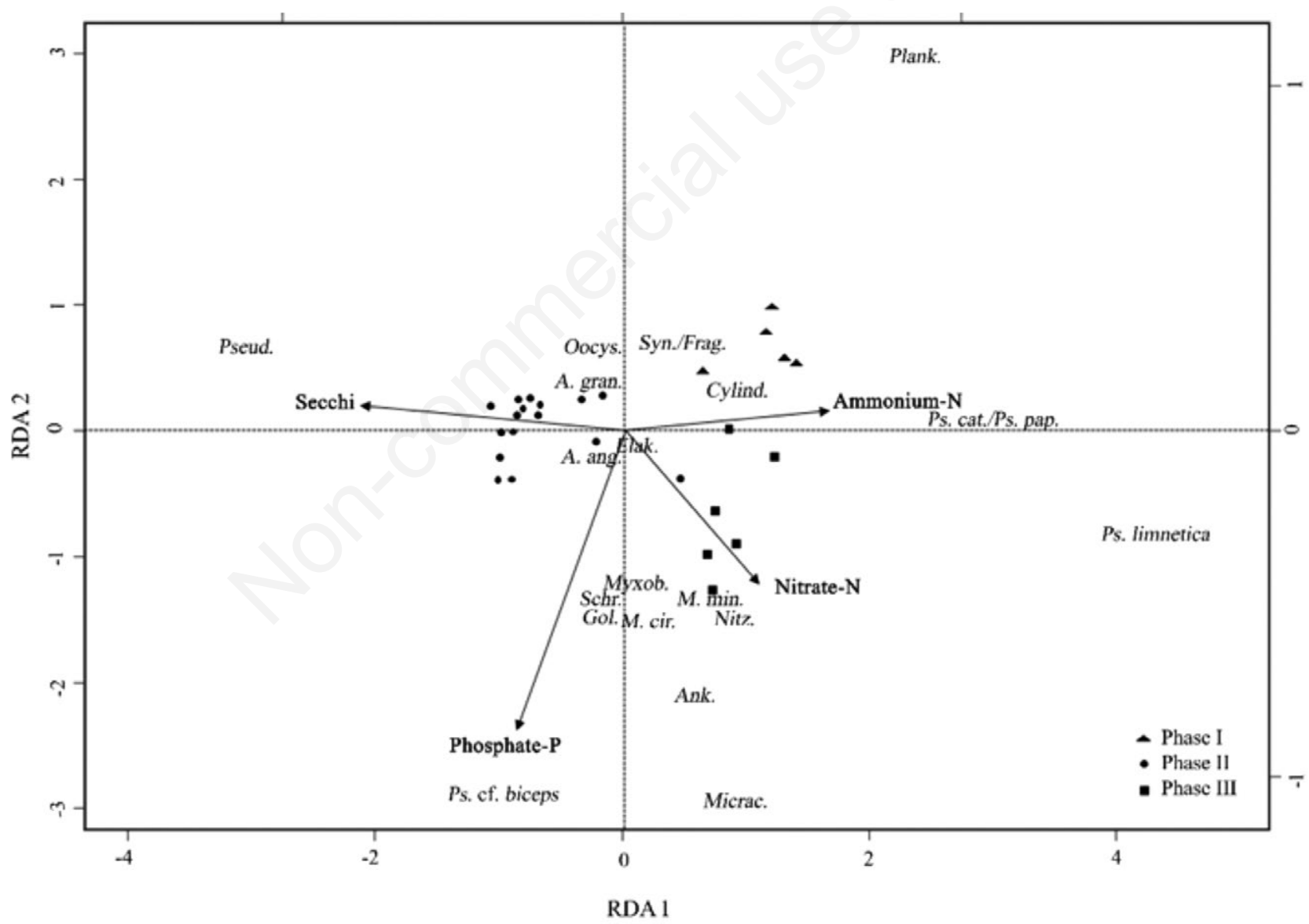

Fig. 5. Triplot diagram for RDA of Castanhão Reservoir data, including only significant $(\mathrm{P}<0.05)$ environmental variables (explanatory variables), phytoplankton 'characterizing taxa' (dependent variables), and samples from respective three temporal phases (I, II and III). RDA 1 and RDA 2 were significant $(\mathrm{P}<0.05)$. Total RDA model was significant $(\mathrm{P}<0.05)$ with an explanatory power of $46.3 \%$ $\left(\mathrm{R}^{2}=0.545\right.$; adjusted $\left.\mathrm{R}^{2}=0.463\right)$. Plank. (Pl. minor and Pl. limnetica); Ps. cat./Ps. pap. (Ps. catenata and Ps. papillaterminata); Cylind. (C. raciborskii and Cylindrospermopsis sp.); Pseud. (Pseudanabaena sp. 1.); Myxob. (Myxobaktron sp.); Schr. (S. setigera); M. cir. (M. circinale); Ank. (A. judayi); M. min. (M. minutum); Oocys. (O. lacustris); Elak. (Elakatothrix sp.); Micrac. (M. pusillum); Gol. (Golenkinia sp.); Nitz. (Nitzschia sp.); Syn./Frag. (S. acus and F. delicatissima); A. gran. (A. granulata var. granulata); A. ang. (A. granulata var. angustissima). 
from March/12, corresponding to the rainy season, while phase II included all samples from August/12 and January/13, both representing the dry season. In turn, phase III included samples from August/2013, which corresponded to the end of the rainy season, since the rainfall in this year lasted until this month (data not shown). The cluster analysis also revealed a high similarity between the phytoplankton composition in phases I and III, which reinforces the influence of climatic seasonality to drive the temporal dynamic of this community. In fact, the development of phytoplankton community in Northeast of Brazil is strongly structured by the seasonal climate (rainy/dry periods) (Chellappa et al., 2009; Brasil et al., 2016).

The highest values of phytoplankton density were found in phase I, being $P$ l. limnetica / Pl. minor $(\mathrm{S} 1)$ the most successful taxa. Other important taxa were Ps. limnetica (S1) and Ps. catenata / Ps. papillaterminata (MP). In this phase, the reservoir was classified as oligotrophic based on the total phosphorous and chlorophyll $a$ concentrations (Santos et al., 2017). It is important to note that the highest phytoplankton density observed in phase I was not associated to a high phytoplankton biomass (chlorophyll $a$ ), precisely due to the dominance of these slender filamentous cyanobacteria, especially $\mathrm{Pl}$. limnetica/ $\mathrm{Pl}$. minor. All these three taxa of cyanobacteria belong to the functional groups S1 and MP and are well adapted to high turbidity conditions (Padisák et al., 2009), what was confirmed by their inverse association with Secchi depth in Castanhão reservoir in RDA.

Although $\mathrm{Pl}$. limnetica/Pl. minor (Delazari-Barroso et al., 2007; Silva and Costa 2015) along with Ps. limnetica (Mohebbi et al., 2015) and Ps. catenata / Ps. papillaterminata (Moura et al., 2007; Silva and Costa, 2015) have been commonly found in mesotrophic to hypertrophic reservoirs, these slender cyanobacteria frequently outcompeted other phytoplankton species under conditions of reduced P supply (Villena and Romo, 2003). In this sense, in the present study, their highest densities, especially of $\mathrm{Pl}$. limnetica/Pl. minor, were mainly associated with reduced phosphate-P supply in phase I, which could be due to the strong thermocline in this period (see Santos et al., 2017). Corroborating this condition, Pl. limnetica was previously shown as a strong indicator of a stratified water column with phosphate-P depletion, probably due to its high-affinity phosphate uptake system (Prentice et al., 2015). In the same way, another study performed in a tropical water supply reservoir (Extremoz Lake, NE Brazil) also showed the dominance of $P$ l. limnetica under low values of phosphate-P (Pinto and Becker, 2014), in accordance with our results.

It is important to highlight that although we have associated the successful of $P$ l. limnetica/Pl. minor with a condition of stratified water column, the water samples in this study were restrictive to subsurface $(1.0 \mathrm{~m})$, and therefore
Pl. limnetica/Ps. minor was recorded in the mixed and turbid surface layer of Castanhão reservoir. This is in agreement with the habitat template (turbid mixed layers) described for codon S1, which this species belongs.

In phase II, the cyanobacteria previously dominant in phase I were partly replaced by other cyanobacteria, mainly Pseudanabaena sp.1 (FG=?) and Ps.cf. biceps (MP). The phytoplankton biomass in phase II was similar to the observed in phase I since the dominance was also of slender filamentous cyanobacteria. Nevertheless, in phase II the reservoir was classified as mesotrophic due to the increase in TP concentration probably driven by the thermocline disruption (Santos et al., 2017).

Pseudanabaena is a genus with tropical planktonic species recorded in lakes and large reservoirs, while Ps. cf. biceps is a species that lives primarily attached to substrate (Komárek and Anagnostidis, 2005; Douma et al., 2009; Klemenčič et al., 2010) and therefore belonging to MP codon. In the Castanhão reservoir, the most remarkable environmental change associated to the emergence of Pseudanabaena sp. 1 in phase II (absent in phase I) was the increase in Secchi depth and the decrease in ammonium-N.

On the other hand, Ps. cf. biceps seemed to be mostly favored by high phosphate-P concentrations, since its average density increased progressively from phase I to phases II and III (Supplementary Tab. 3), following the rise of this nutrient's concentrations. Since Ps. cf. biceps belongs to MP, a codon typical of frequently stirred, inorganically turbid shallow lakes (Padisák et al., 2009), it may also have been favored by decreasing in water volume and thermocline disruption.

Other cyanobacteria with close correlation not only with phosphate increase, but also with nitrate- $\mathrm{N}$ increase was Myxobaktron sp. (X1 ?) that increased in density from phase I to phases II and III (Supplementary Tab. 3). This genus generally forms a minor component of the planktic cyanobacterial biocenosis, but persisted year-round in the tropical regions of northeastern Australia (McGregor, 2013), such as observed in the Castanhão reservoir.

We raised the hypothesis that Myxobaktron sp. would be classified in codon X1 because it reached the better performance along with small green algae (Monoraphidium circinale, Monoraphidium minutum) with fast growth and similar size (length of 5-10 $\mu \mathrm{m}$ ), belonging to X1. Both Myxobaktron sp. and these green algae increased in density in phase III, following the raise in nitrate-N concentrations and the reduction of the reservoir volume. The habitats templates of X1 codon are shallow and hypertrophic/eutrophic environments (Padisák et al., 2009).

In addition to the dominant cyanobacteria in phase II, we highlight the rise in relative abundance of diatoms represented mainly by Aulacoseira granulata var. granulata (P) and A. granulata var. angustissima (P). The functional group $\mathrm{P}$ is associated with higher trophic states and mix- 
ing conditions (Padisák et al., 2009), in accordance with phosphate-P increase and thermocline disruption observed during this phase (Santos et al., 2017).

In phase III, the shade-adapted cyanobacteria that dominated in phase I, which were Pl.limnetica / Pl.minor (S1), Ps. catenata/Ps. papillaterminata (MP) and Ps. limnetica (S1), increased again in density, but at this time with dominance of the last one. Ps. limnetica (S1) is a common species in eutrophic reservoirs (Mohebbi et al., 2015), and in the Castanhão reservoir it seemed to have been more favored mainly by the increase in nitrate-N concentration in phase III. Messyasz et al. (2015) also indicated the dependence of Ps. limnetica to high nitrate-N concentrations.

Another similarity between phases I and III was the absence of Pseudanabaena sp.1, suggesting its sensibility to decreasing water transparency (estimated by Secchi depth). Pseudanabaena sp.1 was also associated with decreasing in ammonium-N concentrations in phase II. It was not possible to assign Pseudanabaena sp.1 to any Reynolds FG, both because the identification did not occur at species level and because it reached the maximum density in a distinct moment (phase II) from the other 'characterizing taxa' of similar morphology (other slender cyanobacteria).

Also in phase III, we highlight among the diatoms Nitzschia sp., belonging to the functional group D, which is indicative of turbid, eutrophic and shallow waters (Reynolds et al., 2002; Padisák et al., 2009; Silva and Costa, 2015). The decrease in water depth, along with the increase in the trophic conditions of the reservoir in phase III, was also suggested by the rise of green algae belonging to the functional group X1, such as A. judayi, M. minutum, $M$. circinale and S. setigera, and belonging to J functional group, represented by Golenkinia sp. According to Padisák et al. (2009), both functional groups, X1 and J, are indicative of shallow and nutrient-enriched systems.

Another functional group within green algae was group F, represented mainly by M. pusillum. F group is typical of mesotrophic/eutrophic waters with clear epilimnion (Padisák et al., 2009), which contrasted with the turbidity condition indicated by the other species, mainly the filamentous cyanobacteria from functional group S1.

In this context, the success of M. pusillum (F) in phase III, along with the other green algae belonging to the functional groups $\mathrm{X} 1$ and $\mathrm{J}$ and the cyanobacteria from $\mathrm{S} 1$, could be due to its ability to growth rapidly under favorable conditions, such as increasing in nutrients, in addition to a possible tolerance to high turbidity conditions. This tolerance is indicated by the fact that the functional group $\mathrm{F}$ is also found in estuaries, which are naturally turbid environments (Costa et al., 2009). Additionally, M. pusillum could have an adaptive advantage over other species due to its ability to use organic compounds (mixotrophy) (Bouarab et al., 2004).
Similarly, Dias (2009) studying the Arcoverde reservoir (also located in the northeastern Brazil semi-arid zone as well) observed the success of species belonging to functional group F, more specifically M. pusillum, along with others from the functional groups $\mathrm{X} 1$ and $\mathrm{S} 1$ in the same period (rainy season). In the Arcoverde reservoir, the rainy period in which these functional groups predominated was characterized by high values of turbidity and dissolved oxygen, as well as elevated concentrations of total dissolved phosphorus, nitrite and nitrate (Dias, 2009). Similarly, in the Castanhão reservoir the key-factors to the rise of M. pusillum in phase III were the increase in nitrate- $\mathrm{N}$ and phosphate-P concentrations, as shown by the RDA.

Finally, in phase III we call attention to the highest phytoplankton biomass, precisely due to the increase of unicellular and mainly colonial green algae, which were mostly induced by the increase in nutrient concentrations, namely nitrate-N and phosphate-P. In fact, the increase in green algae and diatoms in conditions of high nitrate- $\mathrm{N}$ and phosphate-P concentrations could be explained by their reduced uptake rates and thus larger requirements when compared to slender filamentous cyanobacteria. For example, Prentice et al. (2015) showed that the seasonal phytoplankton succession in a large lake was driven by the capacity of phosphate uptake, which resulted into the cyanobacteria dominance under decreased phosphate concentrations during the summer-stratification period and in a diatom/cryptophyte/chlorophyte dominance in surface water with elevated phosphate concentrations. Despite the change in the phytoplankton structure from phase II to III, in this last phase the Castanhão reservoir was also characterized as mesotrophic based on the total phosphorous and chlorophyll $a$ concentrations (Santos et al., 2017).

Overall, our results suggest that in accordance with other studies, shifts in phytoplankton community were associated to changes in nutrient concentrations and water transparency (Medeiros et al., 2015; Costa et al., 2016). Changes in these environmental conditions were closely associated with hydrological changes in the reservoir, namely the reduction in water level due to years of severe drought. However, taking account only the eighteen months of severe drought addressed in this work, the phytoplankton composition seems to have been structured by the climatic rainy / dry regime instead of just by the ongoing decrease in water level.

On the other hand, at least concerning the relative abundance based on density data, this study shows that the dominance of cyanobacteria displayed a decrease from nearly $100 \%$ in phase I to $75 \%$ in phase III, following the ongoing reduction of water level. This finding agrees with other studies performed in semi-arid reservoirs (Medeiros et al., 2015; Costa et al., 2016), that have shown, in contrast with the expectations, that a reduction in water level 
would led to an increase in cyanobacterial dominance (Naselli-Flores et al., 2007; Yang et al., 2016), other phytoplankton groups (such as cryptomonads and diatoms) could also improve their performance under scenarios of extreme drought.

In our study, although the cyanobacteria have dominated throughout the eighteen months of drought, the relative abundance of slender shade-adapted cyanobacteria in codon S1 decreased in phase II and III relative to phase $\mathrm{I}$, due the rise of diatoms in codon $\mathrm{P}$ and $\mathrm{D}$, beyond greenalgae in codons $\mathrm{X} 1, \mathrm{~F}$ and $\mathrm{J}$, most associated to nutrients enrichment environment (Padisák et al., 2009). In this way, the trajectory of phytoplankton succession in water supply reservoirs is not easy to predict, and other particular characteristics such as regional climate (rainy / dry seasons), reservoir type (size and depth), reservoir aging, watershed size and their multiple uses should be considered (Holz, 1997; Medeiros et al., 2015).

In addition to the species already mentioned in the diagnosis of temporal variability of phytoplankton community in Castanhão reservoir, we highlight the common frequency of C. raciborskii $\left(\mathrm{S}_{\mathrm{N}}\right)$ and Cylindrospermopsis sp. $\left(\mathrm{S}_{\mathrm{N}}\right)$ across the study, especially in middle and dam zones during phase I.

Cylindrospermopsis, a taxon belonging to functional group Sn, is associated to mixed environments with high temperatures (Padisák et al., 2009; Bonilla et al., 2012; Soares et al., 2013). Additionally, Cylindrospermopsis is a cyanobacteria with ability to fix nitrogen (Padisák, 1997; Molot, 2017), although this mechanism does not always seem to explain its success in water systems. In fact, C. raciborskii can tolerate variations in nutrient availability, being dominant under a large spectrum of trophic conditions raging from low (Moura et al., 2007) to high nitrogen (Chislock et al., 2014; Silva and Costa, 2015) as well as from low (Bonilla et al., 2012; Prentice et al., 2015) to high phosphorous (Soares et al., 2013). Some studies related this large plasticity of $C$. raciborskii to the existence of ecotypes with different environmental preferences (Piccini et al., 2011; Bonilla et al., 2012). Although in the Castanhão reservoir, $C$. raciborskii and Cylindrospermopsis sp. were not dominant species, the highest mean density of these two species together in phase I (Supplementary Tab. 3) was mainly associated to high ammonium-N, low soluble reactive phosphorus and low Secchi depth.

Taking into account the predicted expansion of $C$. raciborskii in water systems around the world under climate-change scenarios (Bonilla et al., 2012), the knowledge of the temporal dynamic of this species in years of extreme drought conditions brought by the present study is a result of great relevance. Particularly to C. raciborskii, it is very important to know the particular conditions that lead to its high abundance in water supply reservoirs due to its potential for producing cyanotoxins (Sant'Anna et al., 2008). C. raciborskii have been recorded as common and, in fact, dominant in many eutrophic to hypertrophic reservoirs in the Northeast of Brazil (Bouvy et al., 2000; Moura et al., 2007; Silva and Costa, 2015).

Last but not least in importance, we emphasize that, although the shifts in phytoplankton composition seem to be related to extrinsic effects (environmental variables) discussed here, further studies are needed to evaluate to what extent the intrinsic effects (e.g. predation and interspecific competition), could have also influenced the phytoplankton temporal dynamic. Indeed, both intrinsic and extrinsic effects can play a large role in phytoplankton dynamic in reservoirs (Yang et al., 2018).

\section{Comparative analysis: Phytoplankton structure in 2006/2007 versus 2012/2013}

In the first years after the complete flooding of the Castanhão reservoir (2006/2007), a previous study was performed by Molisani et al. (2010). Molisani et al. (2010) classified the system as a whole as mesotrophic based on chlorophyll $a$, Secchi depth and the total phosphorus concentrations, although the inner reservoir zone has been classified as eutrophic. The phytoplankton composition found in this previous period (2006/2007) reflected these mesotrophic/eutrophic conditions.

In turn, in the present survey, according results from Santos et al. (2017), the state index of the reservoir was oligotrophic in phase I and mesotrophic in the others phases. The phytoplankton composition has still indicated mesotrophic/eutrophic conditions, similar to the previous (2006/2007) study, although in phase I the reservoir was dominated by a slender cyanobacteria ( $P l$. limnetica/Pl. minor) very adapted to face phosphate-P deprivation. Both Molisani et al. (2010) and Santos et al. (2017) adopted the Trophic State Index developed by Lamparelli (2004), thereafter published by Cunha et al. (2013).

In both surveys, the phytoplankton biomass in the inner zone was lower than in the middle and dam zones, which is a common behavior in dam reservoirs (Kimmel et al., 1990). In 2006/2007, chlorophyll $a$ ranged from $3.3 \pm 1.4$ to $7.5 \pm 4.5 \mu \mathrm{g} \mathrm{L}^{-1}$ (Molisani et al., 2010), while in the present study from $2.9 \pm 0.5$ to $5 \pm 2.1 \mu \mathrm{g} \mathrm{L}{ }^{-1}$. The lower values of phytoplankton biomass observed recently (2012/2013) may be related to the increase in dominance of slender cyanobacteria over other larger groups that were well represented previously (2006/2007), such as diatoms, cryptomonads and green algae. Additionally, these results agree with Kimmel and Groeger (1986) model that predict a tendency of reduction in phytoplankton production in years after the initial phase of high productivity ('trophic upsurge'), which occurs soon after reservoir filling.

Also, similar to Molisani et al. (2010), we used the functional group approach from Reynolds et al. (2002) 
reviewed by Padisák et al. (2009) to study the phytoplankton dynamic. However, while in Molisani et al. (2010) the main taxa were defined as 'descriptive taxa', which are those with $>5 \%$ of the total phytoplankton density (organisms $\mathrm{L}^{-1}$ ) in at least one sample, in this present work the main taxa have been defined as 'characterizing taxa', and they were obtained by the SIMPER procedure. Despite this, adopting the same criterion, when the list of the 'descriptive taxa' of that previous study (Supplementary Tab. 4) is crossed against the list of 'characterizing taxa' used here (Tab. 1), they match well. Therefore, since similar methodologies were adopted to study the phytoplankton community, which were the Reynolds's functional group approach and a close cut-off value to define the main phytoplankton taxa that were used as indicative of environmental conditions in Castanhão reservoir, the data of both studies could be compared.

In 2006/2007 the main taxa in the inner zone were some diatoms in codons $\mathrm{C}$ and MP, cryptomonads in $\mathrm{Y}$, and green algae in $\mathrm{J}$ and $\mathrm{X} 1$. In turn, in the present work, the same zone was dominated by slender shade-adapted cyanobacteria from the functional group S1, probably related to turbid conditions and the decrease in the availability of inorganic nutrients. Indeed, slender cyanobacteria could be more suitable than green algae, diatoms and cryptomonads to face the reduction of nutrient concentrations, especially phosphate-P (Villena and Romo, 2003; Prentice et al., 2015). This drop in nutrient concentrations in years after the initial phase of reservoir filling agree with the model from Kimmel and Groeger (1986) to describe water quality changes in response to reservoir aging. As consequence of changes in nutrients and light conditions, shifts in phytoplankton composition are expected as well (Holz et al., 1997).

Although water transparency (estimated by Secchi depth) have increased from 2006/2007 to 2012/2013 (in all reservoir zones), the dominance of shade-adapted cyanobacteria (S1) was an indicative that the turbidity could be still considered high for phytoplankton. This increase in water transparency could be, at least in part, also related to a decrease in the relative abundance of large phytoplankton and an increase in dominance of slender cyanobacteria. In addition, $\mathrm{S} 1$ is typical of mixing layers and the lower water volume in 2012/2013 may have favored this FG. It is important to note that lower depth of the reservoir could have favored short-term events of higher turbidity due to the effect of strong winds upon a dropping water column depth, which may have not be detected by Secchi data (an instantaneous measurement), but are reflected by phytoplankton community (an integrative proxy). Additionally, the role of other factors, such as changes in zooplankton structure, that direct impact on the phytoplankton size and composition (Yang et al., 2018), cannot be ruled out as drivers of phytoplankton shifts in the Castanhão reservoir and should be investigated as well.

In the middle and dam zones, during 2006 / 2007 the dominance was already of cyanobacteria (Molisani et al., 2010), similar to the present study. The dominance of cyanobacteria belonging to the functional groups $\mathrm{S} 1$ and MP, typical of mixing and turbid systems (Padisák et al., 2009), persisted during 2012/2013, while the functional group Lo decreased in abundance. In fact, it is important to note the absence of Synechocystis aquatilis in $2012 / 2013$, since it was an abundant species across the zones from Castanhão reservoir in 2006/2007 (Molisani et al., 2010). Synechocystis aquatilis belongs to functional group Lo, which is adapted to both low and high nutrients (Padisák et al., 2009), but is sensitive to prolonged and deep mixing (Reynolds et al., 2002). In this sense, the absence of the functional group Lo between the "characterizing taxa' in 2012/2013, along with a reduction in the reservoir water volume, is indicative of best mixing conditions in 2012/2013 than in 2006/2007, associated with reduced volume and shallower waters as suggested by Santos et al. (2017).

From 2006/2007 to 2012/2013 the middle and dam zones also experienced a drop in nutrient concentrations, just as happened in the inner zone. Regardless of this, it is important to take into mind that even with a decrease in nutrient concentrations and phytoplankton biomass, the system remained still mostly dominated by mesotrophic/eutrophic taxa, especially in phase III. In $2012 / 2013$, along the drought months, the system experienced an ongoing increase in trophic state from oligotrophic to mesotrophic, resulting in the rising of the phytoplankton species more associated to a nutrient enrichment environment.

Cylindrospermopsis raciborskii $\left(\mathrm{S}_{\mathrm{N}}\right)$, a potentially toxic cyanobacterium, was found in 2006/2007 and persisted as a frequent species in 2012/2013 in the middle and dam zones. In addition, other species have appeared, such as Cylindrospermopsis sp., which were absent in 2006/2007 (Molisani et al., 2010). Other cyanobacteria observed in the present study and absent in 2006/2007 were Pseudanabaena cf. biceps (MP) and Myxobaktron sp. (X1 ?).

Finally, we highlight the replacement of the dominant diatom Achnanthidium minutissimum (MP) in the middle and dam zones in 2006/2007 (Molisani et al., 2010) by other diatoms represented mainly by Nitzschia sp. (12-25 $\mu \mathrm{m})(\mathrm{D})$, followed by Aulacoseira granulata (P) in 2012/2013. A. minutissimum is a species of smaller size than A. granulata and Nitzschia sp., which could indicate the more favorable mixing conditions to the diatoms of larger sizes in the middle and dam zones in 2012/2013. Indeed, according to Padisák et al. (2009), A. granulata (P) is associated to mixing layers, while Nitzschia sp. to shallow turbid waters. 


\section{CONCLUSIONS}

Our study demonstrates that the temporal shifts in phytoplankton community in eighteen months of severe drought in a large reservoir from the Brazilian semi-arid region was associated with sub-surface phosphate-P, ammonium- $\mathrm{N}$ and nitrate- $\mathrm{N}$ concentrations, along with water transparency changes. We demonstrated a shift in phytoplankton composition, from slender cyanobacteria (S1 and MP) favored by turbid and poor phosphate-P conditions in Phase I to other slender cyanobacteria (FG ?) probably favored by increase in Secchi depth and decrease in ammonium-N in phase II. In turn, in phase III the ascension of opportunistic and fast-growing green algae (X1, F and J) were driven by the increase of phosphate-P and nitrate- $\mathrm{N}$ in the reservoir.

In general, although some species substitutions have occurred, especially in the inlet zone, when comparing the first years after the completing flooding of the Castanhão reservoir (2006-2007) with eight years later (2012-2013), the phytoplankton composition, with emphasis on the dominance of slender filamentous cyanobacteria, continued to indicate mesotrophic/eutrophic and turbid conditions of the system, though they have been facing the decrease in inorganic nutrients. The large dominance of functional group S1 (typical of turbid and mixing layers) in the last years was an indicative that the turbidity could still be considered high to phytoplankton, favoring the slender shade-adapted cyanobacteria, especially Planktolyngbya limnetica/Pl. minor and Pseudanabaena limnetica.

The dominance of cyanobacteria from the functional group S1 during most of the time in 2012/2013 was also an indicative of increase in mixing conditions in comparison to 2006/2007. On the same way, the best mixing conditions during drought years related to lower reservoir volume, was indicated by the lack of the functional group Lo between the 'characterizing taxa' in 2012/2013, along with the replacement of small diatoms (MP and C) by large diatoms belonging to functional groups $\mathrm{D}$ and $\mathrm{P}$.

\section{ACKNOWLEDGMENTS}

The work was supported by the Brazilian National Research Council (CNPq) and the Ceará State Research Support Foundation (FUNCAP), Brazil. The authors wish to thank Dr. Tallita C. L. Tavares who assisted in the proofreading of the manuscript.

\section{REFERENCES}

Bicudo CEM, Menezes M, 2006. [Gêneros de algas de águas continentais do Brasil: chave para identificação e descrições]. [Book in Portuguese]. 2. Rima, São Carlos: 490 pp.
Bonilla S, Aubriot L, Soares MCS, Gonzalez-Piana M, Fabre A, Huszar VL, Lürling M, Antoniades D, Padisák J, Kruk C, 2012. What drives the distribution of the bloom-forming cyanobacteria Planktothrix agardhii and Cylindrospermopsis raciborskii? FEMS Microbiol. Eco. 79:594-607.

Bouarab L, Dauta A, Loudiki M, 2004. Heterotrophic and mixotrophic growth of Micractinium pusillum Fresenius in the presence of acetate and glucose: effect of light and acetate gradient concentration. Water Res. 38:2706-2712.

Bouvy M, Falcão D, Marinho M, Pagano M, Moura A, 2000. Occurrence of Cylindrospermopsis (Cyanobacteria) in 39 Brazilian tropical reservoirs during the 1998 drought. Aquat. Microb. Ecol. 23:13-27.

Bouvy M, Molica R, De Oliveira S, Marinho M, Beker B, 1999. Dynamics of a toxic cyanobacterial bloom (Cylindrospermopsis raciborskii) in a shallow reservoir in the semi-arid region of Northeast Brazil. Aquat. Microb. Ecol. 20:285-297.

Bouvy M, Nascimento SM, Molica RJ, Ferreira A, Huszar V, Azevedo SM, 2003. Limnological features in Tapacurá reservoir (Northeast Brazil) during a severe drought. Hydrobiologia 493:115-130.

Bendschneider K, Robinson RJ, 1952. A new spectrophotometric method for the determination of nitrite in seawater. J. Marine Res. 11:87-96.

Braga GG, Becker V, Oliveira JNPD, Mendonça Junior JRD, Bezerra AFDM, Torres LM, Galvão ÂMF, Mattos A, 2015. Influence of extended drought on water quality in tropical reservoirs in a semi-arid region. Acta Limnol. Brasil. 27:15-23.

Brasil J, Attayde JL, Vasconcelos FR, Dantas DD, Huszar VL, 2016. Drought-induced water-level reduction favors cyanobacteria blooms in tropical shallow lakes. Hydrobiologia 770:145-164.

Brassac NM, Ludwig TA, 2003. [Fragilariaceae (Bacillariophyceae) de rios da bacia do Iguaçu, Estado do Paraná, Brasil].[Article in Portuguese]. Ver. Bras. Botânica 26:311-318.

Câmara F, Rocha O, Pessoa E, Chellappa S, Chellappa N, 2015. Morphofunctional changes of phytoplankton community during pluvial anomaly in a tropical reservoir. Braz. J. Biol. 75:628-637.

Chaves FÍB, Lima PDF, Leitão RC, Paulino WD, Santaella ST, 2013. Influence of rainfall on the trophic status of a Brazilian semi-arid reservoir. Acta Scientiarum Biological Sciences 35:505-511.

Chellappa NT, Chellappa T, Câmara FR, Rocha O, Chellappa S, 2009. Impact of stress and disturbance factors on the phytoplankton communities in northeastern Brazil reservoir. Limnologica 39:273-282.

Chislock MF, Sharp KL, Wilson AE, 2014. Cylindrospermopsis raciborskii dominates under very low and high nitrogen-tophosphorus ratios. Water Res.49:207-214.

Cirilo JA, 2008. [Políticas públicas de recursos hídricos para o semi-árido].[Article in Portuguese]. Estudos Avançados 22:61-82.

COGERH (Companhia de Gestão dos Recursos Hídricos) 2011. [Inventario Ambiental Açude Castanhão].[Book in Portuguese]. Geosolos Consultoria, Projetos e Serviços Ltda, Fortaleza: $142 \mathrm{pp}$.

Costa L, Huszar V, Ovalle A, 2009. Phytoplankton functional groups in a tropical estuary: hydrological control and nutrient limitation. Estuar. Coast. 32:508-521. 
Costa MRA, Attayde JL, Becker V, 2016. Effects of water level reduction on the dynamics of phytoplankton functional groups in tropical semi-arid shallow lakes. Hydrobiologia 778:75-89.

Cronberg G, Komárek J, 2004. Some nostocalean cyanoprokaryotes from lentic habitats of Eastern and Southern Africa. Nova Hedwigia 78:71-106.

Cunha DGF, Calijuri MC, Lamparelli MC, 2013. A trophic state index for tropical/subtropical reservoirs (TSItsr). Ecol. Engin. 60:126-134.

Delazari-Barroso A, Sant'anna CL, Senna PAC, 2007. Phytoplankton from Duas Bocas Reservoir, Espírito Santo State, Brazil (except diatoms). Hoehnea 34:211-229.

Dias SN, 2009. [Ecologia do fitoplâncton no reservatório Arcoverde: estudo nictemeral e sazonal]. [Doctoral Thesis in Portuguese]. Accessed: 14 June 2014. Available from: http://www.tede2.ufrpe.br:8080/tede/handle/tede2/4936

DNOCS (Departamento Nacional de Obras Contra as Secas), 2014. [Açude Castanhão].[Report in Portuguese]. Accessed: 10 June 2014. Available from: http://www.dnocs.gov.br

Douma M, Loudiki M, Oudra B, Mouhri K, Ouahid Y, Del Campo FF, 2009. Taxonomic diversity and toxicological assessment of Cyanobacteria in Moroccan inland waters. Revue des sciences de l'eau 22:435-449.

Edler L, Elbrächter M, 2010. The Utermöhl method for quantitative phytoplankton analysis, p. 13-20. In: B. Karlson, C. Cusack and E. Bresnan (eds.), Microscopic and molecular methods for quantitative phytoplankton analysis. UNESCO, Paris: 110 pp.

FUNCEME (Fundação Cearense de Meteorologia e Recursos Hídricos), 2014. [Chuvas: Séries Históricas].[Report in Portuguese]. Accessed in: October 2014. Available from: http://www.funceme.br/index.php/areas/tempo/downloaddeseries-historicas

Holz, JC, Hoagland, KD, Spawn, RL, Popp A., Andersen JL, 1997. Phytoplankton community response to reservoir aging, 1968-92. Hydrobiologia 346:183-192.

ISO, 1992. Water quality measurement of biochemical parameters spectrophotometric determination of chlorophyll-a concentration. ISO Norm 10260. International Organization for Standardization, Geneva.

Jirsa F, Gruber M, Stojanovic A, Omondi SO, Mader D, Körner W, Schagerl M, 2013. Major and trace element geochemistry of Lake Bogoria and Lake Nakuru, Kenya, during extreme draught. Geochemistry 73:275-282.

Kimmel BL, Groeger AW, 1986. Limnological and ecological changes associated with reservoir aging, p. 103-109. In: G.E. Hall and M.J. Van Den Avyle (eds.), Reservoir fisheries management: strategies for the 80's. American Fisheries Society, Bethesda.

Kimmel B, Lind O, Paulson L, 1990. Reservoir primary production, p. 133-193. In: K. Thornton, B. Kimmel and F. Payne (eds.), Reservoir limnology: ecological perspective. J. Wiley \& Sons, Chichester.

Klemenčič AK, Smolar-Žvanut N, Istenič D, Griessler-Bulc T, 2010. Algal community patterns in Slovenian bogs along environmental gradients. Biologia 65:422-437.

Komárek J, 2001. Review of the cyanoprokaryotic genus Romeria. Czech Phycology 1:5-19.

Komárek J, 2013. [Cyanoprokaryota 3. Teil/Part 3: Heterocytous
Genera]. In: B. Büdel, G. Gärtner, L. Krienitz and M. Schagerl (eds). [Süsswasserflora von Mitteleuropa].[Book in German]. Springer Spektrum, Berlin.

Komárek J, Anagnostidis K, 2000. [Cyanoprokaryota 1. Teil/Part 1: Chroococcales]. In: H. Ettl, G. Gärtner, H. Heyning, D. Mollenhaueer (eds), [Süsswasserflora von Mitteleuropa]. [Book in German]. Springer Spektrum, Berlin.

Komárek J, Anagnostidis K, 2005. [Cyanoprokaryota 2. Teil/Part 2: Oscillatoriales]. In: B. Büdel, L. Krienitz, G. Gärtner and M. Schagerl (eds), [Süsswasserflora von Mitteleuropa].[Book in German]. Springer Spektrum, Berlin.

Koroleff F, 1970. Revised version of direct determination ammonia of natural waters as indophenol blue. Information on techniques and methods for sea water analysis. ICES Interlab. Rep. 3:19-22.

Kruk C, Huszar VL, Peeters ET, Bonilla S, Costa L, Lürling M, Reynolds C, Scheffer M, 2010. A morphological classification capturing functional variation in phytoplankton. Freshwater Biology 55:614-627.

Lamparelli MC, 2004. [Graus de trofia em corpos d'água do Estado de São Paulo: avaliação dos métodos de monitoramento].[Doctoral Thesis in Portuguese]. Accessed: 15 Oct 2017. Available from: www.teses.usp.br/teses/disponiveis/41/ 41134/tde-20032006.../TeseLamparelli2004.pdf

Marengo JA, Alves LM, Soares WR, Rodriguez DA, Camargo H, Riveros MP, Pabló AD, 2013. Two contrasting severe seasonal extremes in tropical South America in 2012: flood in Amazonia and drought in Northeast Brazil. J. Climate 26:9137-9154.

Marengo JA, Bernasconi M, 2015. Regional differences in aridity/drought conditions over Northeast Brazil: present state and future projections. Climatic Change 129:103-115.

Marengo JA, Cunha AP, Alves LM, 2016. [A seca de 2012-15 no semi-árido do Nordeste do Brasil no contexto histórico].[Article in Portuguese]. Climanálise 3:49-54.

Mcgregor GB, 2013. Freshwater Cyanobacteria of North-Eastern Australia: 2. Chroococcales. Phytotaxa 133:1-130.

Medeiros LC, Mattos A, Lürling M, Becker V, 2015. Is the future blue-green or brown? The effects of extreme events on phytoplankton dynamics in a semi-arid man-made lake. Aquat. Ecol. 49:293-307.

Messyasz B, Gąbka M, Barylski J, Nowicki G, Lamentowicz Ł, Goździcka-Józefiak A, Rybak A, Dondajewska R, Burchardt L, 2015. Phytoplankton, culturable bacteria and their relationships along environmental gradients in a stratified eutrophic lake. Carpath. J. Earth Environ. Sci 10:41-52.

Mohebbi F, Riahi H, Sheidaei M, Shariatmadari Z, Manaffar R, 2015. Environmental control of the dominant phytoplankton in Aras Reservoir (Iran): A multivariate approach. Lakes Reservoirs 20:206-215.

Molisani MM, Barroso HS, Becker H, Moreira MOP, Hijo CAG, Monte TM, Vasconcellos GH, 2010. Trophic state, phytoplankton assemblages and limnological diagnosis of the Castanhão Reservoir, CE, Brazil. Acta Limnol. Brasil. 22:1-12.

Molisani MM, Do Monte TM, Vasconcellos GH, De Souza Barroso H, Moreira MOP, Becker H, De Rezende CE, Franco MaL, De Farias EGG, De Camargo PB, 2015. Relative effects of nutrient emission from intensive cage aquaculture on the semi-arid reservoir water quality. Environ. Monit. Assess. 187:707. 
Molot LA, 2017. The effectiveness of cyanobacteria nitrogen fixation: Review of bench top and pilot scale nitrogen removal studies and implications for nitrogen removal programs. Environ. Rev. 25:292-295.

Mosley LM, 2015. Drought impacts on the water quality of freshwater systems; review and integration. Earth-Sci. Rev. 140:203-214.

Mosley LM, Zammit B, Leyden E, Heneker TM, Hipsey MR, Skinner D, Aldridge KT, 2012. The impact of extreme low flows on the water quality of the Lower Murray River and Lakes (South Australia). Water Res. Manag. 26:3923-3946.

Moura AN, Bittencourt-Oliveira MC, Dantas ÊW, Neto JDTA, 2007. Phytoplanktonic associations: a tool to understanding dominance events in a tropical Brazilian reservoir. Acta Bot. Bras. 21:641-648.

Murphy J, Riley JP, 1962. A modified single solution method for the determination of phosphate in natural waters. Analytica Chimica Acta 27:31-36.

Naselli-Flores L, 2003. Man-made lakes in Mediterranean semiarid climate: the strange case of Dr Deep Lake and Mr Shallow Lake. Hydrobiologia 506:13-21.

Naselli-Flores L, Barone R, Chorus I, Kurmayer R, 2007. Toxic cyanobacterial blooms in reservoirs under a semiarid Mediterranean climate: the magnification of a problem. Environ. Toxicol. 22:399-404.

Nóbrega RS, Santiago GACF, 2014. [Tendência de temperatura na superfície do mar nos oceanos atlântico e pacífico e variabilidade de precipitação em Pernambuco].[Article in Portuguese]. Mercator (Fortaleza) 13:107-118.

Oksanen J, 2015. Multivariate Analysis of Ecological Communities in R: vegan tutorial.

Padisák J, 1997. Cylindrospermopsis raciborskii (Woloszynska) Seenayya et Subba Raju, an expanding, highly adaptive cyanobacterium: worldwide distribution and review of its ecology. Arch. Hydrobiol. Supplementband Monographische Beitrage 107:563-593.

Padisák J, Crossetti LO, Naselli-Flores L, 2009. Use and misuse in the application of the phytoplankton functional classification: a critical review with updates. Hydrobiologia 621:1-19.

Piccini C, Aubriot L, Fabre A, Amaral V, González-Piana M, Giani A, Figueredo CC, Vidal L, Kruk C, Bonilla S, 2011. Genetic and eco-physiological differences of South American Cylindrospermopsis raciborskii isolates support the hypothesis of multiple ecotypes. Harmful Algae 10:644-653.

Pinto TDS, Becker V, 2014. Diel dynamic of phytoplankton functional groups in a tropical water supply, Extremoz Lake, northeastern Brazil. Acta Limnol. Brasil. 26:356-366.

Prentice MJ, Brien KR, Hamilton DP, Burford MA, 2015. Highand low-affinity phosphate uptake and its effect on phytoplankton dominance in a phosphate-depauperate lake. Aquat. Microb.1 Ecol. 75:139-153.
Rangel LM, Soares MCS, Paiva R, Silva LHS, 2016. Morphology-based functional groups as effective indicators of phytoplankton dynamics in a tropical cyanobacteria-dominated transitional river-reservoir system. Ecol. Indic. 64:217-227.

Reynolds CS, Huszar V, Kruk C, Naselli-Flores L, Melo S, 2002. Towards a functional classification of the freshwater phytoplankton. J. Plankton Res. 24:417-428.

Reynolds CS, 2006. The ecology of phytoplankton. Cambridge University Press, Cambridge: 535 pp.

Rodrigues LC, Pivato BM, Vieira LCG, Bovo-Scomparin VM, Bortolini JC, Pineda A, Train S, 2017. Use of phytoplankton functional groups as a model of spatial and temporal patterns in reservoirs: a case study in a reservoir of central Brazil. Hydrobiologia 805:147-161.

Sant'anna CL, Azevedo MTDP, Werner VR, Dogo CR, Rios FR, De Carvalho LR, 2008. Review of toxic species of Cyanobacteria in Brazil. Algol. Stud. 126:251-265.

Santos JA, Marins RV, Aguiar JE, Challar G, Silva FA, Lacerda LD, 2017. Hydrochemistry and trophic state change in a large reservoir in the Brazilian Northeast region under intense drought conditions. J. Limnol. 76:41-51.

Silva APC, Costa IAS, 2015. Biomonitoring ecological status of two reservoirs of the Brazilian semi-arid using phytoplankton assemblages (Q index). Acta Limnol. Brasil. 27:1-14.

Soares MCS, Huszar VL, Miranda MN, Mello MM, Roland F, Lürling M, 2013. Cyanobacterial dominance in Brazil: distribution and environmental preferences. Hydrobiologia 717:1-12.

Utermohl H, 1958. [Zur Vervollkommung der quantitativen phytoplankton-methodik].[Article in German]. Mitt. Intern. Ver. Theor. Amgew. Limnol. 9:1-38.

Valderrama JC, 1981. The simultaneous analysis of total nitrogen and total phosphorus in natural waters. Mar. Chem. 10:109-122.

Villena M-J, Romo S, 2003. Phytoplankton changes in a shallow Mediterranean lake (Albufera of Valencia, Spain) after sewage diversion. Hydrobiologia 506:281-287.

World Commission on Dams, 2000. Dams and development: a new framework for decision-making. Earthscam Publications, London: 404 pp.

Yang J, Lv H, Liu, L, Yu X, Chen H, 2016. Decline in water level boosts cyanobacteria dominance in subtropical reservoirs. Sci. Total Environ. 557:445-452.

Yang JR, Lv H, Isabwe A, Liu L, Yu X, Chen H, Yang J, 2017. Disturbance-induced phytoplankton regime shifts and recovery of cyanobacteria dominance in two subtropical reservoirs. Water Res. 120:52-63.

Yang W, Zheng Z, Zheng C, Lu K, Ding D, Zhu J, 2018. Temporal variations in a phytoplankton community in a subtropical reservoir: An interplay of extrinsic and intrinsic community effects. Sci. Total Environ. 612:720-727. 